Marina Rincon Sartori

Excreção de nitrogênio em embriões de iguana Iguana iguana (Reptilia; Squamata)

Nitrogen excretion in the green iguana (Iguana iguana) embryos (Reptilia; Squamata)

São Paulo 
Marina Rincon Sartori

\section{Excreção de nitrogênio em embriões de iguana Iguana iguana (Reptilia; Squamata)}

Nitrogen excretion in the green iguana (Iguana iguana) embryos (Reptilia; Squamata)

Dissertação apresentada ao Instituto de Biociências da Universidade de São Paulo, para a obtenção do Título de Mestre em Ciências, na Área de Fisiologia Geral.

Orientador: Augusto Shinya Abe

São Paulo 


\section{Ficha Catalográfica}

Sartori, Marina Rincon

Excreção de nitrogênio em embriões de iguana Iguana iguana (Reptilia; Squamata)

57 páginas

Dissertação (Mestrado) - Instituto de Biociências da Universidade de São Paulo. Departamento de Fisiologia Geral.

1. desenvolvimento embrionário 2. uréia 3 . répteis I. Universidade de São Paulo. Instituto de Biociências. Departamento de Fisiologia Geral.

\section{Comissão Julgadora:}

Prof(a). Dr(a).

Prof(a). Dr(a).

Prof. Dr. Augusto Shinya Abe

Orientador 
À minha família e principalmente à meu pai (i.m.). 
"Não pretendemos que as coisas mudem, se sempre fazemos o mesmo. A crise é a melhor benção que pode ocorrer com as pessoas e países, porque a crise traz progressos. A criatividade nasce da angústia, como o dia nasce da noite escura. É na crise que nascem as invenções, os descobrimentos e as grandes estratégias. Quem supera a crise, supera a si mesmo sem ficar 'superado'. Quem atribui à crise seus fracassos e penúrias, violenta seu próprio talento e respeita mais os problemas do que as soluções. A verdadeira crise é a crise da incompetência... Sem crise não há desafios; sem desafios, a vida é uma rotina, uma lenta agonia. Sem crise não há mérito. É na crise que se aflora o melhor de cada um..."

Albert Einstein 


\section{Agradecimentos}

Estes anos de mestrado representaram para mim um grande amadurecimento tanto do lado pessoal quanto profissional. Assim meus agradecimentos se dirigem a pessoas diretamente e indiretamente envolvidas neste processo. Em primeiro lugar agradeço ao meu orientador, Augusto Shinya Abe que me encaminha na vida científica desde muito antes do início deste trabalho. Também sou grata aos professores Denis Andrade e Cleo Leite pela ajuda com muitas dúvidas que surgiram. Em especial também sou grata ao Tedinho, que pacientemente me ensinou muito e que me inspirou quanto à dedicação ao trabalho.

Agradeço às professoras do Depto. De Morfologia e Fisiologia Animal da UNESP de Jaboticabal, Laura Satiko Okada Nakaghi e Isabel Cristina Boleli que me auxiliaram no início das análises morfológicas dos embriões.

À FAPESP pela bolsa concedida durante o período de 2009 e 2011.

À todos os alunos do Jacarezário, pelas discussões, viagens de congresso e churrascos: Adriana, Bruna, Fernanda, Gabrielle, Jussara, Luciana, Manuel, Rafael, Renatoe Rodrigo. Aos técnicos, Carlos, Joniel, Fernando e Cris, com quem sempre posso contar com auxílio.

Ao pessoal da fisiologia da USP de São Paulo que me abrigou e me ajudou nas disciplinas, Cristiéle, Aline, Amandinha e Cadu.Aos amigos que me acompanham desde muito tempo e mesmo os que se encontram mais afastadosmas que sempre estão presentes em boas lembranças, Mariana Franchi, Cibele, Mariana Alegre, Marcela Arelaro, Zigrid, Lígia, Lúcia, Alexandre Castellar, Bia, Wanessa, Michele, Maiby, dentre muitas outras pessoas. Um carinhoso agradecimento ao Tiago pela companhia e apoio.

E um agradecimento especial à minha família, que é um grande suporte e força para superar os percalços que por ventura ocorrem em nossas vidas e que me conforta sempre em momentos felizes ou tristes. Ao meu pai, que esteve presente no início desta jornada e que agora acompanha a sua finalização lá de cima. Saudade... 


\section{Índice}

Introdução Geral

01

Capítulo 1. Estágios de desenvolvimento embrionário do lagarto iguana (Iguana iguana)

08

Capítulo 2. Excreção de nitrogênio em embriões de Iguana iguana

Discussão Geral

Conclusões

Resumo (GERAL)

Abstract

Referências Bibliográficas

Apêndices 


\section{Introdução Geral}

A conservação e o balanço da água corpórea foram de fundamental importância na ocupação do ambiente terrestre pelos vertebrados. Associado a esta questão, está a eliminação dos excretas nitrogenados, que demanda perda de água do organismo. Os tecidos vivos metabolizam lipídios, carboidratos e proteínas, produzindo dióxido de carbono, água e amônia, e este último sendo um composto tóxico que deve ser rapidamente eliminado (WARREN e LIEM, 1994). A maioria dos animais terrestres converte a amônia em uréia ou ácido úrico, compostos que podem ser mais concentrados em fluidos corpóreos que a amônia mas sem os seus efeitos tóxicos (WRIGTH, 1995), que podem ser desde a atuação no sistema nervoso central a alterações no potencial de membrana (McKHANN e TOWER, 1961). A uréia pode ser retida no organismo por um determinado tempo, porém em altas concentrações também pode tornar-se tóxica, afetando o balanço osmótico das células. Por sua vez, o ácido úrico é relativamente inerte e insolúvel, podendo ser concentrado e eliminado com pequeno volume de água (McNABB e McNABB, 1980).

Nos diferentes grupos de vertebrados ocorre uma correlação entre os tipos de excretas nitrogenados com o modo de reprodução e o hábitat do animal (WARREN e LIEM, 1994). Devido a grande solubilidade da amônia, animais que possuem acesso a fontes abundantes de água, como peixes teleósteos, larvas de anfíbios e crocodilos, eliminam este tipo de excreta sem maiores dificuldades. A amônia possui difusão extremamente rápida, podendo ser perdida em grande parte pela superfície do corpo e principalmente pelas brânquias, não precisando ser excretada pelo rim (RANDALL e WRIGHT, 1987). Por outro lado, animais que vivem em ambientes com restrição hídrica enfrentam o problema da conservação de água corpórea e assim recorrem à uréia (ureotelismo) ou ao ácido úrico (uricotelismo) como principal forma de excreta, propiciando uma maior conservação de água no organismo (WARREN e LIEM, 1994). A uréia é excretada por anfíbios adultos e pelos mamíferos, enquanto o ácido úrico é excretado por lagartos, serpentes e aves. Algumas tartarugas, por sua vez, podem excretar os três tipos de excretas nitrogenados na dependência da disponibilidade de água (MOYLE, 1949). Muitos animais acumulam uréia para fins 
de osmorregulação, como ocorre em elasmobrânquios marinhos (WRIGHT, 1995) e anfíbios em estivação (CARTLEDGE et al., 2006).

O ovo amniótico foi um grande marco para a ocupação efetiva do ambiente terrestre pelos vertebrados devido às funções das membranas extra-embrionárias, âmnion, córion e alantóide, tornando os animais independentes da reprodução restrita ao ambiente aquático (PACKARD, 1966). Essa independência do meio aquático é particularmente propiciada pelas membranas âmnion e córion, que envolvem o embrião em um meio líquido, protegendo-o da dessecação durante todo o desenvolvimento. $\mathrm{O}$ alantóide exerce as funções de trocas gasosas e armazenamento de excretas e o vitelo serve como um suprimento abundante de nutrientes (ROMER, 1957). A casca evoluiu para proteger o ovo de danos mecânicos e de infecções por microorganismos (RAHN e PAGANELLI, 1979).

O ovo cleidóico, típico de répteis e aves, se comporta como um sistema fechado, em que as trocas com o ambiente se limitam aos gases respiratórios e a um pequeno volume de água, que ocorre através de difusão pela casca (VLECK, 1991). Em répteis, com a variação na composição da casca, pode-se observar uma tendência filogenética através da classificação dos ovos em três categorias: ovos de casca pergaminácea, coriácea e calcária (VLECK e HOYT, 1991).

O tipo de casca influencia na condutância de gases e absorção de água e, dessa forma, os efeitos hídricos do ambiente afetam de forma particular os diferentes grupos de répteis (PACKARD et al., 1982). Dentre os Squamata, com exceção de alguns membros das famílias Gekkonidae e Dibamidae, a maioria dos ovos possui cascas do tipo pergaminácea, extremamente flexível e com membranas finas e elásticas. Estes ovos permitem uma maior troca de água e gases respiratórios, com consequente aumento de volume durante o desenvolvimento. A maioria dos quelônios deposita ovos com casca de flexibilidade intermediária, possuindo uma camada calcária bem definida, composta de aragonita, denominados de ovos coriáceos. (PACKARD et al., 1982). Ovos de camadas rígidas, compostas de carbonato de cálcio na forma de calcita, pertencem aos crocodilianos, algumas espécies de tartarugas e uns poucos lagartos, e sua estrutura se aproxima à dos ovos de aves (PACKARD et al, 1982; TRACY e SNELL, 1985). Neste último caso os embriões são forçados a subsistir com apenas a água disponível desde a oviposição com adição de pequena quantidade de água formada metabolicamente (PACKARD e PACKARD, 1983). 
No caso de répteis e aves, a excreção de produtos nitrogenados menos tóxicos é um pré-requisito para o longo período embrionário que ocorre dentro do ovo (PORTER, 1972). Nesta fase o alantóide atua temporariamente como uma bexiga urinária estocando os resíduos nitrogenados resultantes do metabolismo do embrião (ROMER, 1957). Assim, a excreção de ácido úrico, a uricotelia, seria supostamente uma adaptação vantajosa para os répteis, o que proporcionaria aos embriões maior conservação de água no interior dos ovos cleidóicos (NEEDHAM, 1931). Porém, contrariamente às expectativas, o que se observa é que os embriões de répteis parecem produzir maiores proporções de uréia, mesmo nas espécies que possuem ovos com casca calcária e rígida, comprometendo dessa forma a água que seria mais diretamente conservada para o suporte e desenvolvimento do embrião (PACKARD e PACKARD, 1983). Comprometem ainda a água que seria eventualmente utilizada durante o período final da incubação, no caso de alterações abruptas nas condições hídricas do ambiente (PACKARD e PACKARD, 1987).

Uma explicação para o acúmulo de uréia no alantóide seria o aumento no potencial hídrico do ovo possibilitando-o absorver água osmoticamente do solo (PACKARD e PACKARD, 1987; JORGENSEN, 1997), uma teoria válida apenas para ovos de casca pergaminácea, que permitem a troca de água com o ambiente. Porém, o que se observa no trabalho de PACKARD e PACKARD (1983) com o quelônio Trionyx spiniferus é que, apesar desta espécie possuir ovos com casca calcária, também são encontrados altos valores de uréia e o ácido úrico não é encontrado em valores detectáveis. Foi sugerido que estes animais não dependem da conservação de água, não necessitando da uricotelia, sendo assim um exemplo de plasticidade e adaptabilidade de processos fisiológicos às demandas do ambiente, embora esta hipótese não seja ainda comprovada. (PACKARD e PACKARD, 1983). No caso da serpente Coluber constrictor observa-se que ocorre uma alteração na proporção dos compostos nitrogenados ao longo do desenvolvimento, em que é reduzida a concentração de uréia e aumentada a de ácido úrico ao final do período de incubação (CLARK, 1953; PACKARD e PACKARD, 1987).

Embora alguns trabalhos de excreção embrionária tenham sido realizados para elucidar a questão da ureotelia, poucos destes estudos foram realizados com os Squamata e todos consideram a idade cronológica do embrião como referencial. A utilização de classificações baseadas apenas na idade cronológica pode resultar em 
falhas e controvérsias (HAMBURGER e HAMILTON, 1951). Diversos fatores alteram a taxa de desenvolvimento embrionário. O modo de reprodução entre os Squamata pode ser ovíparo ou vivíparo, seguindo um padrão contínuo (SHINE, 1983), o que leva a oviposição a ocorrer em um amplo espectro de estágios entre as diferentes espécies ovíparas (ANDREWS e MATHIES, 2000). O tempo em que os ovos ficam retidos, desenvolvendo-se no oviduto da fêmea, pode refletir no número de estágios pós oviposição. Além disso, mesmo dentro de uma única espécie há variações entre ninhadas que podem ser substanciais (BILLET et al., 1985). Em estudos comparativos, outra complicação é a condição ambiental, como temperatura e umidade, que afetam a taxa de desenvolvimento dos embriões (DEEMING e FERGUSON, 1991). Além disso, a realização de experimentos na ausência da definição de estágios embrionários pode levar a vieses na condução dos experimentos e na obtenção de resultados (ANDREWS, 2004).

Muitos fatores levam à falta de correlação da idade cronológica com a estrutural, como a definição exata do momento de deposição dos ovos e a ocorrência de variações na taxa de desenvolvimento, que ocorre mesmo dentro de uma única ninhada (IUNGMAN et al, 2008). Portanto, uma série padrão de desenvolvimento embrionário é a base primária para organizar a informação em qualquer estudo embriológico, seja descritivo ou experimental (IUNGMAN et al, 2008). Além de estudos embriológicos, as séries morfológicas de desenvolvimento também são úteis para a abordagem de aspectos ecológicos e evolutivos (ANDREWS, 2004).

A biologia do desenvolvimento é muito baseada em tabelas, figuras, ilustrações ou fotos com textos descritivos, utilizadas para separar a sequência de eventos embrionários em estágios padrão. Historicamente houve muito questionamento sobre a própria possibilidade de se designar estágios e sua relevância, já que as tabelas seriam apenas relativas a uma organização de eventos e não um resultado empírico. Hoje é reconhecido que as tabelas são ferramentas úteis em laboratórios e que os padrões descritos moldam, e são moldados, pelas mudanças conceituais na embriologia de vertebrados ao longo do tempo (HOPWOOD, 2007).

O estado experimental da morfologia do desenvolvimento embrionário de répteis ainda encontra-se pouco estudado, com relativamente poucas espécies das diferentes ordens descritas ao longo dos estágios de desenvolvimento, ao contrário do que ocorre com os anfíbios e as aves (BELLAIRS, 1991). Dessa forma, descrições 
gerais do desenvolvimento reptiliano ainda são muito baseadas no desenvolvimento de aves. Porém, comparando-se o desenvolvimento embrionário inicial de répteis e de aves, é possível identificar semelhanças e diferenças. Como exemplo de similaridade há o padrão de clivagem e um exemplo de disparidade é o processo de gastrulação, que nas aves é relacionado à linha primitiva e que nos répteis ocorre associada a um blastóporo (HUBERT, 1985).

Para possibilitar análises quantitativas é necessária uma ampla disponibilidade de séries de desenvolvimento embrionário nos diferentes táxons de répteis (ANDREWS, 2004). A determinação da variação entre as séries do desenvolvimento embrionário, entre diferentes espécies ou mesmo entre ninhadas de uma mesma espécie, é uma ferramenta importante para minimizar ou entender diferenças encontradas em experimentos nesta fase de desenvolvimento (ANDREWS, 2004).

Assim, este trabalho visa avaliar a natureza e concentração dos excretas nitrogenados do embrião do lagarto tropical, Iguana iguana, ao longo do desenvolvimento embrionário, correlacionando-os com o respectivo estágio do embrião. Como não há uma tabela padrão para os estágios embrionários de lagartos, será confeccionada para a espécie, que servirá de base para comparação com as demais famílias, a partir da caracterização de cada estágio. 


\section{A espécie Iguana iguana}

Iguana iguana é um lagarto da família Iguanidae, que juntamente com as famílias Corytophanidae, Phrynosomatidae, Crotaphytidae e Tropidurinae são agrupadas no clado monofilético Iguania. Nas análises cladísticas baseadas em morfologia Iguania é considerado como o grupo com maior dicotomia em relação a todos os demais taxa, englobados no clado Scleroglossa. Algumas das características diagnósticas de Iguania são: fusão da premaxila, presença de tuberosidade prefrontal, proceso ventromedial do pterigóide, quilhas presentes na vértebra cervical e planos de autotomia caudal presentes posteriormente aos processos transversais (CONRAD, 2008).

A distribuição da espécie Iguana iguana é restrita às áreas tropicais e subtropicais da América. Os iguanas são herbívoros e dependem da presença de uma flora microbiana fermentativa no trato intestinal para realizar a degradação de fibras vegetais. Esta flora é adquirida pelos filhotes em contato com co-específicos (TROYER, 1982). Os filhotes selecionam dietas com maior porcentagem de proteína digerível e possuem um menor trânsito intestinal, para suportar a maior demanda energética e para a construção dos tecidos corpóreos durante o crescimento (TROYER, 1984a e 1984b).

A maturidade sexual nos iguanas é atingida no terceiro ano de vida (HENDERSON, 1974). As fêmeas cavam ninhos solitários ou em grupos (RAND e DUGAN, 1983) e as desovas são sazonais, ocorrendo nos meses mais quentes do ano (HIRTH, 1963). As fêmeas depositam ovos com cascas muito flexíveis, em que ocorrem apenas esparsos cristais de material calcáreo entre as fibras da membrana da casca (PACKARD et al., 1982), o que ocasiona uma absorção de grande volume de água do meio de incubação. Licht e Moberly (1965) reportaram que a eclosão ocorre após 73 dias de incubação, e que a temperatura ótima de incubação é de $30^{\circ} \mathrm{C}$. 
Figura 1: Imagens de fêmeas de iguana, A) antes da desova - note a protuberância dos ovos na região ventral; B) após desova.
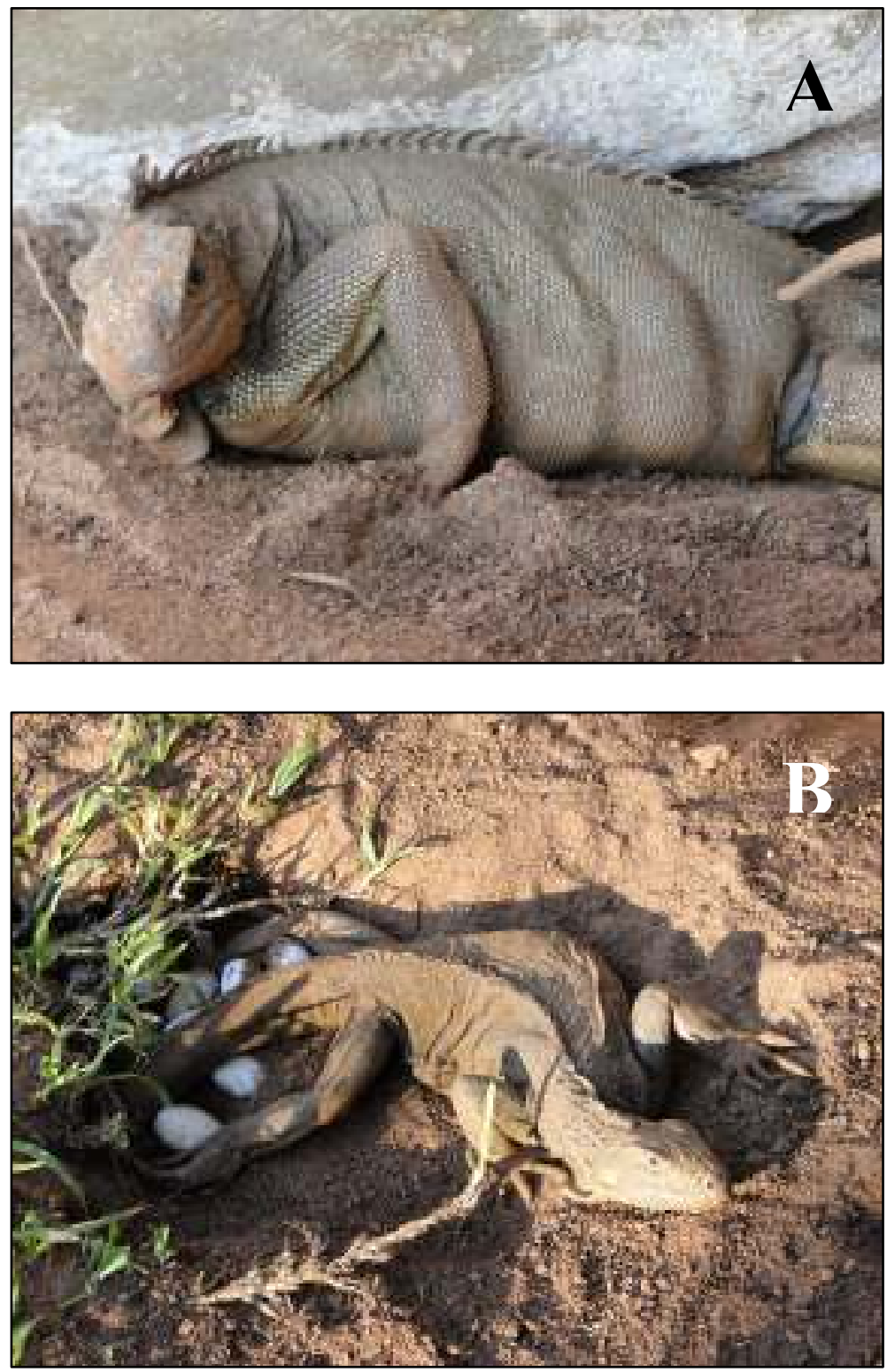


\section{Capítulo I}

\section{Estágios de desenvolvimento embrionário do lagarto iguana, Iguana iguana}

\section{Abstract}

Squamates are extremely diverse and interesting for comparative investigations of embryonic development. Characterization of developmental stages is a primary basis for organizing information in comparative embryological studies. This work establishes a standard table of embryonic stages for the green iguana, Iguana iguana, an oviparous lizard, by describing the external morphology during the embryonic development after oviposition and compares the embryological events with species of the two Squamate clades, Iguania and Scleroglossa. Eggs from several clutches were incubated in vermiculite at constant temperature of $30^{\circ} \mathrm{C}$ and saturating humidity. Throughout the development, sets of embryos were fixed, examined under a stereomicroscope and photographed. Eggs are retained in the oviduct during the initial development until the neurula stage. The post-ovipositional development lasted an average of 72 days and 18 stages were described. The development can be divided more generally into three phases: the earliest, characterized mainly by the number and size of the branchial arches, size and pigmentation of the optic vesicle and development of primary brain vesicles. In the intermediate phase, the key features are the morphology of the limbs and the progress of maxillary and mandibulary processes. At the later phase, the stages are related to specie-specific characteristics, scales formation, and pigmentation.

\section{Resumo}

Os Squamata são extremamente diversos e interessantes para investigações comparativas do desenvolvimento embrionário. A caracterização da sequência do desenvolvimento é a base primária para se organizar as informações em estudos 
embriológicos comparativos. Este trabalho estabelece uma tabela padrão de estágios embrionários para o iguana, Iguana iguana, um lagarto ovíparo, a partir da caracterização descritiva da morfologia externa ao longo do desenvolvimento embrionário, após a oviposição e comparações dos eventos embriológicos com demais espécies dos dois clados de Squamata, Iguania e Scleroglossa. Ovos de várias ninhadas foram incubados em vermiculita à temperatura constante de $30^{\circ} \mathrm{C}$ e umidade saturante. Ao longo do desenvolvimento séries de embriões foram fixados e posteriormente analisados sob estereomicroscópio e fotografados. Os ovos são retidos no oviduto da fêmea durante o período inicial de desenvolvimento, até o final da etapa de nêurula. Ao longo do período de desenvolvimento do iguana, que tem a duração média de 72 dias, foram definidos 18 estágios. O desenvolvimento pode ser dividido, de uma forma mais geral, em três fases: a inicial caracterizada principalmente pelo número e formato dos arcos branquiais, tamanho e pigmentação da vesícula óptica e desenvolvimento das vesículas cerebrais primárias. Nos estágios da fase intermediária as características-chave são a morfologia dos membros e os processos maxilares e mandibulares. Na fase final, os estágios estão relacionados com os caracteres espécie-específicos, formação de escamas e pigmentação.

\section{Introdução}

O grupo dos Squamata é o maior dentre os répteis em número e diversidade, mesmo assim, em estudos embriológicos receberam menos atenção do que espécies que parecem possuir maior interesse de conservação, como crocodilianos e quelônios (BILLET et al., 1985; WISE et al., 2009). Os Squamata apresentam uma grande diversidade de modos e ciclos reprodutivos, representando uma rica e interessante fonte para estudos comparativos de desenvolvimento (BILLET et al., 1985). Apesar disso, apenas poucas descrições e tabelas de estágios embrionários estão disponíveis na literatura do grupo, o que constitui um entrave para estudos e experimentos sobre o tema (NORO et al, 2009). Ademais, alguns representantes do grupo Squamata possuem uma posição filogenética conflituosa e informações sobre a embriogênese poderiam ser utilizadas como uma ferramenta adicional para auxiliar na resolução destas questões. Até o momento, as informações sobre a reprodução de Squamata são 
restritas e concentradas em poucas espécies européias e norte-americanas (GIRONS, 1985).

Os lagartos são divididos em dois clados, Scleroglossa e Iguania. Também inclui três grupos com ausência de membros que são as serpentes, as anfisbênias e os lagartos da família Dibamidae, que apesar de serem agrupados com o grupo Scleroglossa possuem uma posição filogenética controversa (TOWNSEND et al., 2004). Os embriões são uma importante fonte de estudos filogenéticos, pois apresentam homologias que podem ser extrapolados para a evolução de reptilianos e demais vertebrados (BOUGHNER et al., 2007). Durante o desenvolvimento se expressam muitos mecanismos conservados e compartilhados por vários grupos que são responsáveis por controlar a formação de padrões de expressão de genes. (SLACK et al., 1993). Quando estes padrões de expressão são modificados ocorrem variações morfológicas que podem ser observadas entre as espécies (RICHARDSON et al., 1999). Assim, comparações embriológicas entre os diferentes grupos podem ser utilizadas para identificar semelhanças e diferenças com base na filogenia. Para estas comparações pode ser utilizado o conceito de heterocronia, que tenta ligar a evolução a eventos e processos de desenvolvimento com base na ordem, tempo e taxa de processos de desenvolvimento (SMITH, 2003).

Para os lagartos a tabela mais frequentemente utilizada como referência é a da espécie vivípara do grupo Scleroglossa, Lacerta vivipara (DUFAURE e HUBERT, 1961). Mas outras tabelas de desenvolvimento foram recentemente publicadas para diferentes espécies ovíparas. Dentro de Scleroglossa há tabelas para os representantes da família basal Gekkonidae, Paroedura pictus (NORO et al., 2009) e Eublepharis macularius (WISE et al., 2009). Para o grupo Iguania há tabelas para a família Iguanidae, com a espécie Liolaemus tenuis tenuis; (LEMUS et al., 1981), para a família Agamidae com as espécies Calotes versicolor (MUTHUKKARUPPAN et al., 1970) e Agama impalearis (MOUDEN et al, 2000) e para Polychrotidae, com a espécie Anolis sagrei (SANGER et al, 2008). Para serpentes a tabela mais citada é a de Zehr (1962) para a espécie vivípara Thamnophis sirtalis sirtalis, mas também há tabelas de estágios para Naja kaouthia (JACKSON, 2002) e Python sebae (BOUGHNER et al., 2007).

Neste estudo foi estabelecida uma tabela de estágios embrionários para um representante do grupo Iguania, o lagarto tropical Iguana iguana, da família 
Iguanidae, com o objetivo de trazer subsídios para futuros estudos fisiológicos, ecológicos e evolutivos. Os eventos da tabela foram comparados com as demais tabelas disponíveis e as diferenças estruturais e heterocrônicas analisadas entre os clados Iguania e Scleroglossa.

\section{Materiais e Métodos}

Os ovos foram coletados de uma colônia de iguana mantidos em cativeiro, em um criadouro científico mantido no Campus da UNESP de Rio Claro, conhecido como Jacarezário. Ovos recém coletados foram transferidos para caixas plásticas, sendo parcialmente cobertos com vermiculita úmida e incubados em uma sala climatizada (Eletrolab modelo EL011), à temperatura constante de $30^{\circ} \mathrm{C}\left( \pm 0,1^{\circ} \mathrm{C}\right)$. No dia da desova e a cada um dos nove dias subsequentes, cinco ovos de uma mesma ninhada foram fixados em solução formalina a 10\%. Posteriormente, a cada dois dias até o momento da eclosão quatro ovos de duas diferentes ninhadas foram fixados. Todos os embriões foram analisados sob estereomicroscópio, com aumento máximo de 50 vezes, no laboratório do Departamento de Morfologia e Fisiologia Animal da FCAVUNESP, Campus de Jaboticabal e os demais no Laboratório do Jacarezário, UNESP, Campus Rio Claro. Para as fotos dos embriões iniciais (até estágio 10) foi utilizado o estereomicroscópio com câmera digital acoplada, Nikon SMZ1500 e o software NISElementsD, em uma faixa de zoom entre 0,75x e 11,5x. Para os demais estágios as fotos foram realizadas com a câmera digital Canon PowerShot G9, utilizando o zoom até o máximo valor que permitisse nitidez (máximo 6x).

\section{Resultados}

Nas três ninhadas examinadas o tempo de incubação foi em média de 72 dias $( \pm 2)$. Baseados na morfologia externa foram identificados e descritos 18 estágios pósoviposição. No momento da oviposição os embriões encontrados foram identificados como o terceiro estágio, "Early Limb Bud", definido por Sanger e colaboradores (2008), para o gênero de lagartos Anolis, de uma família próxima à Iguanidae. Este 
estágio também pode ser relacionado ao estágio 28 da tabela de Dufaure e Hubert (1961).

Estágio 1 (1-2 dias após a oviposição): embrião translúcido; contagem acurada de somitos é difícil, portanto não será uma característica utilizada na descrição dos estágios. Brotos dos membros anteriores e posteriores estão presentes. Broto da cauda presente, com uma pequena volta. Olhos não possuem pigmentação e diferenciação da lente e cálice óptico é fracamente distinguível. Três ou quatro arcos branquiais são visíveis, sendo o primeiro e segundo maiores que os demais. Três vesículas cerebrais são claramente distinguíveis, o prosencéfalo, mesencéfalo e rombencéfalo; constrições tele-diencefálicas e meso-metencefálicas começam a se diferenciar. Vesícula ótica é evidente, na forma de uma leve depressão, localizada dorsalmente aos arcos branquiais. Placódio nasal notório. Primórdio do coração na forma de proeminência tubular e torcida. Primórdio do fígado visível como uma condensação de tecido, localizado logo abaixo do primórdio do coração.

Figura 1: Detalhes do estágio embrionário 1 de I. iguana; em a) arcos branquiais de 1 a 4, b) broto do membro anterior $(\mathrm{ma})$, c) broto do membro posterior (mp). Legenda: $\mathrm{ab}=$ arco branquial; $\mathrm{c}=$ primórdio do coração; ot $=$ vesícula ótica; $\mathrm{ma}=$ broto do membro anterior; $\mathrm{f}=$ primórdio do fígado; $\mathrm{mp}=$ broto do membro posterior; $\mathrm{bc}=$ broto da cauda. Escala $=200 \mu \mathrm{m}$.
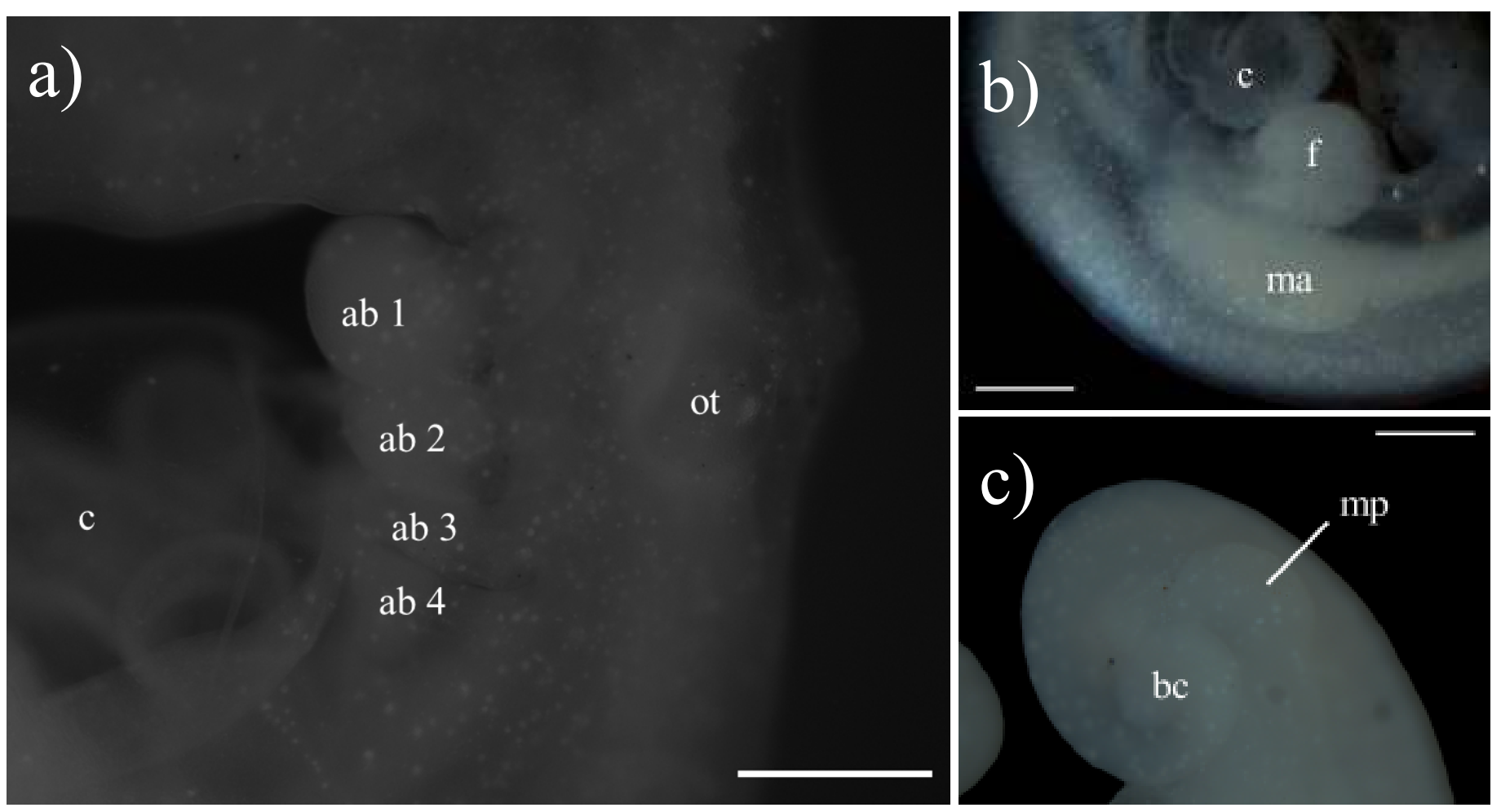
Estágio 2 (3-4 dias após a oviposição): cinco arcos branquiais distinguíveis. Brotos dos membros anteriores e posteriores maiores que no estágio anterior. Broto do membro anterior mais longo que o posterior. Nos olhos a fissura coróide é aparente e inicia-se a pigmentação, que ocorre sutilmente na retina e mais fortemente na porção mediana do olho, perpendicularmente à fissura. Mesencéfalo mais pronunciado; metencéfalo e diencéfalo evidentes.

Estágio 3 (5-6 dias após a oviposição): o segundo arco branquial cobre parcialmente o terceiro. Ocorre uma torção cervical no embrião, fazendo com que a cabeça esteja mais próxima da cauda. Placódio nasal menos evidente. Pode-se observar mais claramente a fissura coróide, a pigmentação e o contorno das lentes. Membros anteriores crescem em direção ântero-posterior e os membros posteriores crescem dorso-ventralmente. Metencéfalo/mielencéfalo e diencéfalo mais expandidos e discerníveis.

Figura 2: Detalhes dos estágios a) 2, com destaque dos arcos branquiais de número 1 a 5 visíveis; b) 3, com broto do membro posterior em destaque; c) 3 ; da vescícula óptica com pigmentação e fissura coróide evidentes. Legenda: $a b=\operatorname{arco}$ branquial; $\mathrm{c}=$ primórdio de coração; ot $=$ vesícula ótica; opt $=$ vesícula óptica; $\mathrm{f}=$ primórdio de fígado; $\mathrm{bc}=$ broto da cauda; $\mathrm{mp}=$ broto do membro posterior; $\mathrm{fc}=$ fissura coróide . Escala $=200 \mu \mathrm{m}$.
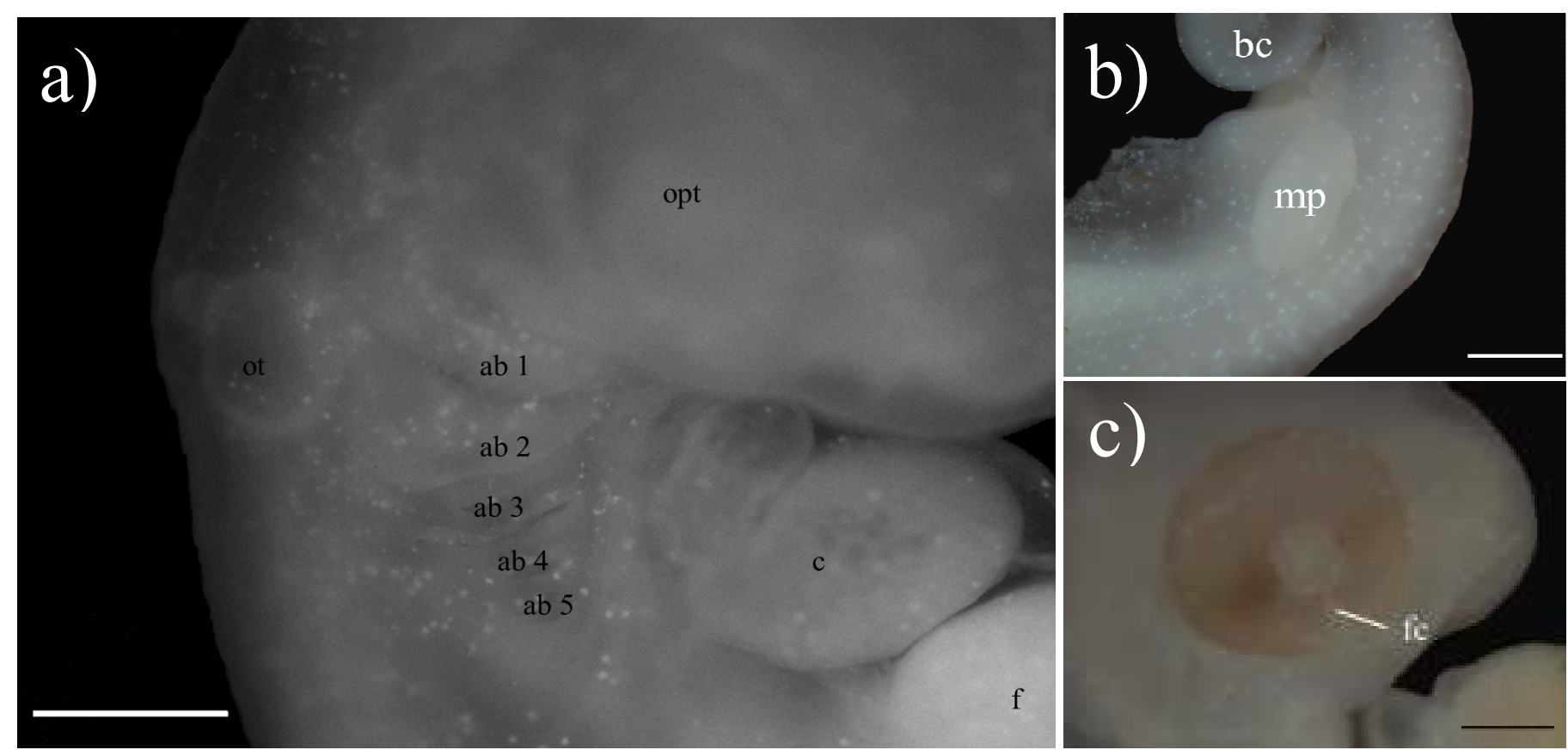
Figura 3: fotos dos embriões de Iguana iguana com os respectivos números de estágio embrionários, de $1 \mathrm{a}$. Escala $=2 \mathrm{~mm}$.
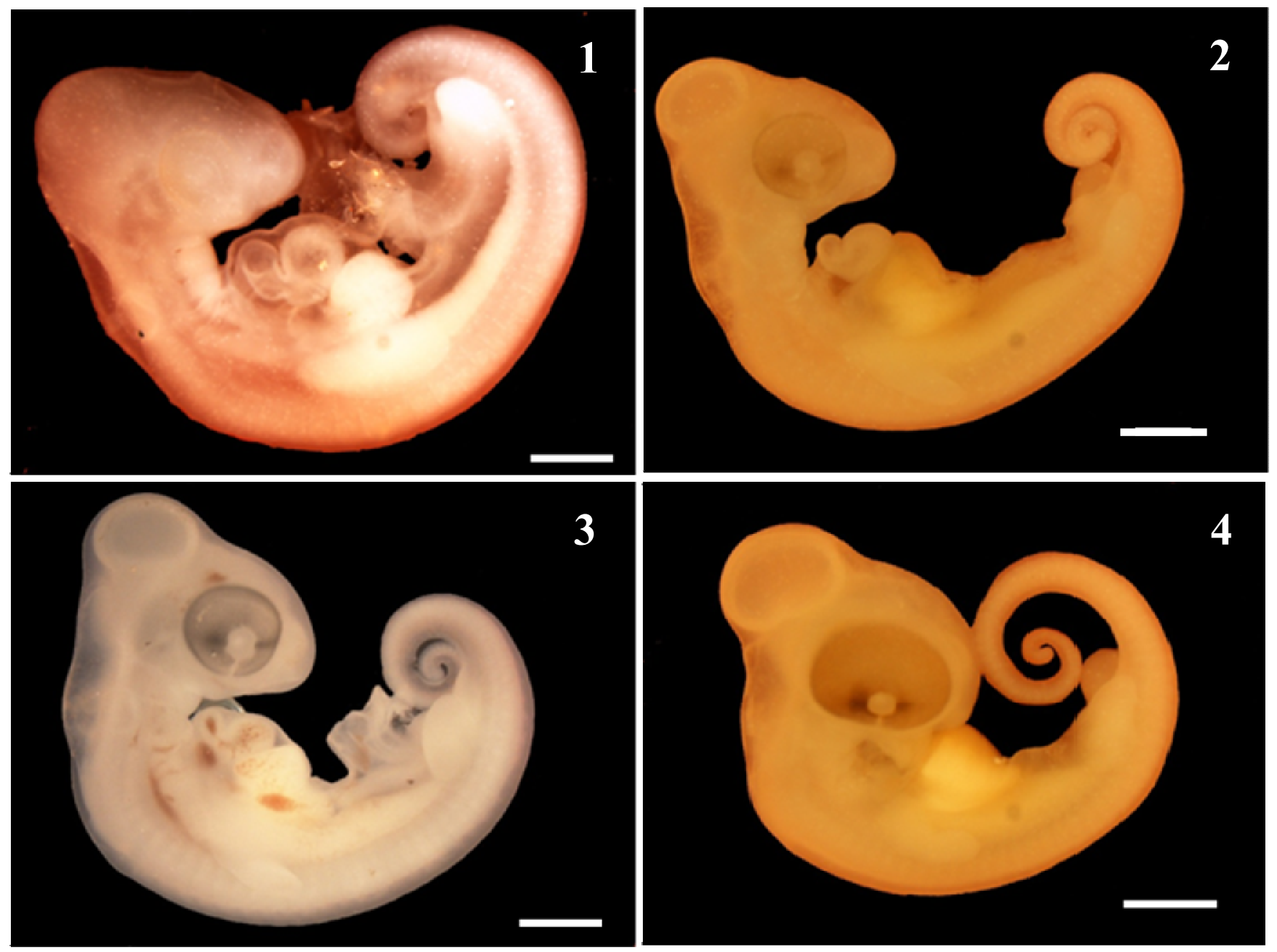

Estágio 4 (7-8 dias após a oviposição): processos maxilares distinguíveis; processos mandibulares projetando-se anteriormente. Mesencéfalo mais expandido; lobos telencefálicos dividem-se. Primeiro e segundo arcos branquiais se fundem; o terceiro arco encobre o quarto e o quinto. Olhos em forma de elipse, conspicuamente maiores. Extremidade dos brotos dos membros anteriores e posteriores apresentam-se levemente achatados.

Estágio 5 (9-10 dias após a oviposição): extremidade dos brotos dos membros se achata mais conspicuamente, tomando a forma de raquete e formando o autopódio. Processos maxilares estendem-se até a porção anterior dos olhos enquanto os 
processos mandibulares estendem-se até a porção posterior da lente dos olhos. Os olhos apresentam pigmentação uniforme na retina e a fissura coróide está fechada. Lobos diencefálicos mais expandidos.

Estágio 6 (de 10 a 14 dias após a oviposição): na margem do autopódio delineiam-se ranhuras e inicia-se uma fraca condensação do tecidos digitais. É possível visualizar as articulações dos membros, diferenciando-se o zeugopódio e o estilopódio. Processo maxilar une-se ao processo nasal lateral, enquanto o processo mandibular estende-se até a porção medial dos olhos. Nos olhos, ocorre o início da diferenciação das íris. Mesencéfalo inicia divisão em dois lobos, e encontra-se menos pronunciado.

Figura 4: fotos dos embriões de I. iguana nos estágios de 5 a 8 . Escala $=1 \mathrm{~cm}$.
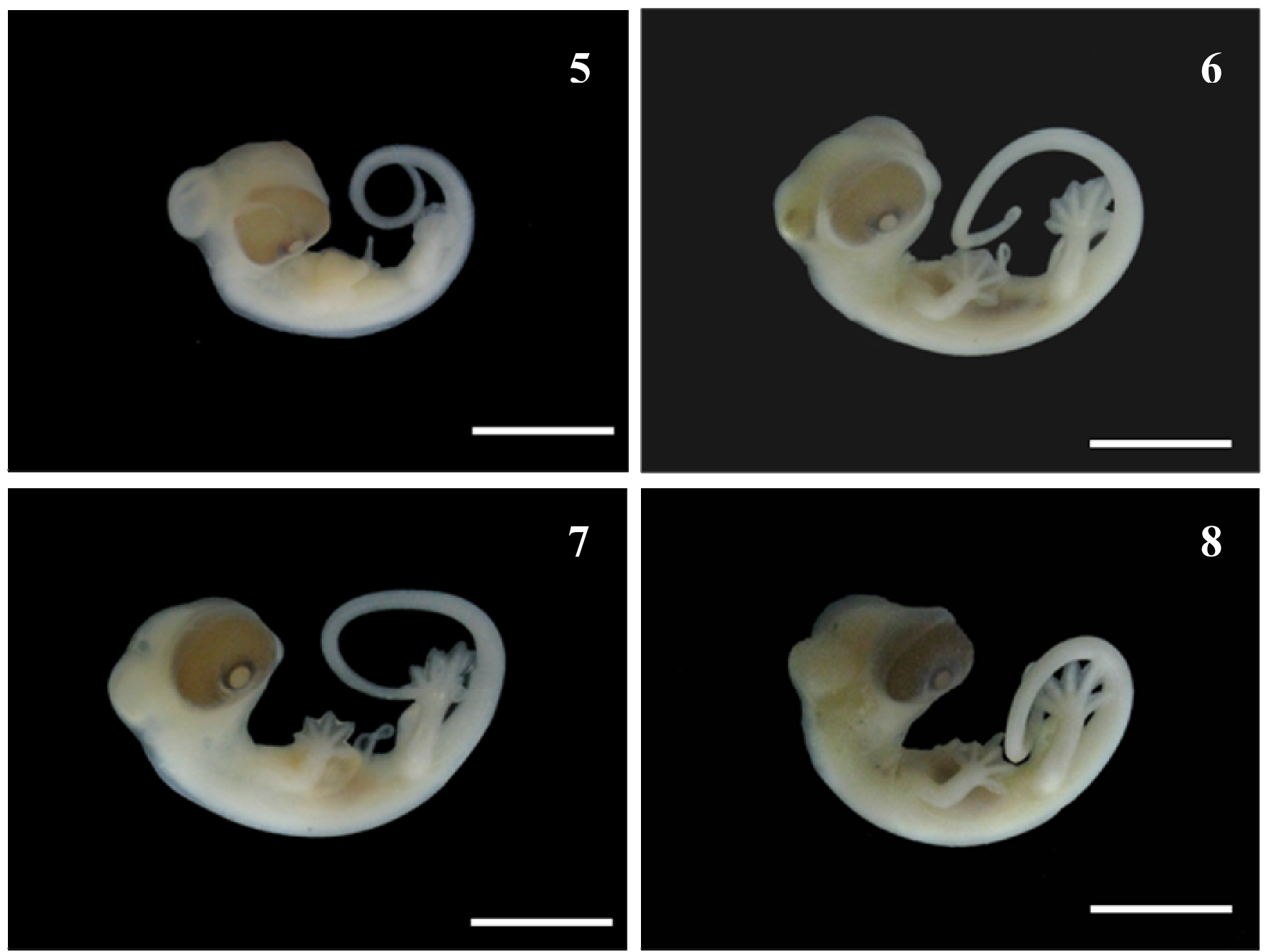
Estágio 7 (de 14 a 18 dias após a oviposição): condensação completa dos dígitos dos membros e interligação dos mesmos por uma fina membrana (membrana interdigital). Duas protuberâncias arredondadas projetam-se a partir da papila genital (primórdio do hemipênis). Íris dos olhos completamente formada. Ductos endolinfáticos, de coloração branca, visíveis. Processo maxilar une-se ao processo nasal medial, delimitando a narina e formando o lábio superior. Lobos diencefálicos e mesencefálicos menores e mais próximos.

Estágio 8 (de 18 a 22 dias após a oviposição): dígitos de ambos os membros apresentam a membrana interdigital parcialmente reduzida. Maxila superior completamente formada e processo mandibular alcançando a mesma direção do processo maxilar. Hemipênis mais desenvolvido. Mesencéfalo de menor tamanho e mais próximo do diencéfalo. Pineal com coloração escura, bem evidente.

Estágio 9 (de 22 a 26 dias após a oviposição): membrana interdigital completamente reduzida; dígitos diferenciam-se em tamanho, sendo que o dígito medial é maior que os demais. Parede do corpo completamente formada, com a abertura apenas para as artérias e veias. Início da formação das pálpebras.

Estágio 10 (de 26 a 30 dias após a oviposição): início do desenvolvimento da prega gular, na forma de uma estreita expansão de pele serrilhada abaixo da mandíbula, com base mais alargada na porção em contato com o pescoço. Depressão do ouvido mais evidente. Presença de escleras ópticas ao redor das íris dos olhos. Hemipênis mais desenvolvido. Início da formação das garras com condensação na extremidade dos dígitos. Primeiras papilas (primórdios de escamas) aparecem na pele do dorso, mas são visíveis apenas sob maior magnificação.

Estágio 11 (de 30 a 34 dias após a oviposição): pela primeira vez aparecem os escudos nucais, na região occipital, apresentam-se dispersos e de pequeno tamanho. Observa-se o início da formação da crista occipital e dorsal.

Estágio 12 (de 34 a 38 dias após a oviposição): garras inteiramente formadas apresentam curvatura e coloração branca. Globos oculares menos proeminentes. Pálpebra cobre a maior porção do olho, exceto a íris e lentes. 
Figura 5: fotos dos embriões de Iguana iguana nos estágios de 9 a 12 . Escala $=1 \mathrm{~cm}$.
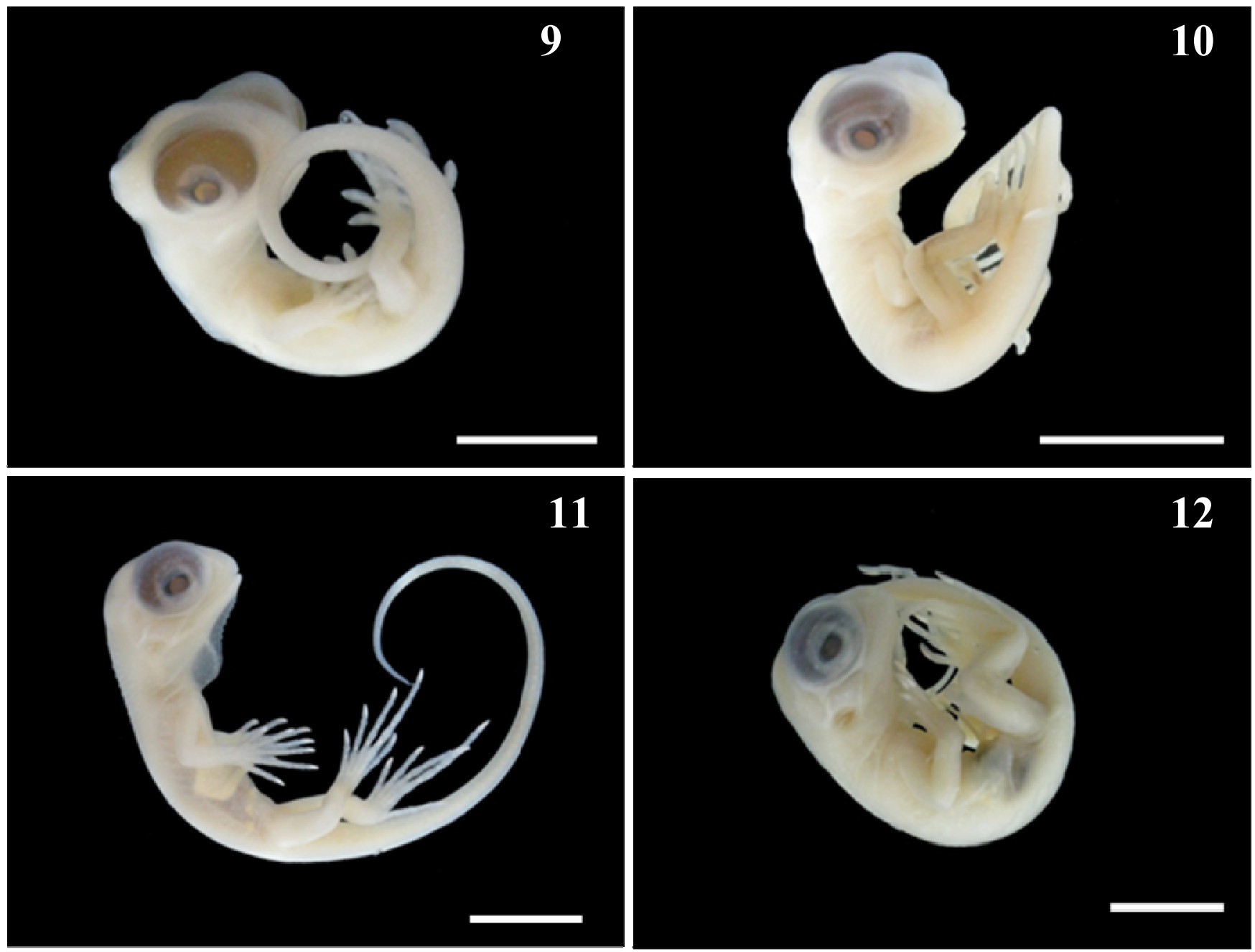
Figura 6: Detalhes do desenvolvimento embrionário de I. iguana. a e b) representam respectivamente membro anterior e posterior do estágio 6; c e d) representam respectivamente membro anterior e posterior do estágio 7; e) representa membro anterior do estágio 8 e f) representa membros e dígitos e garras do estágio 10 , e o hemipênis em evidência. Escala $=100 \mu \mathrm{m}$.
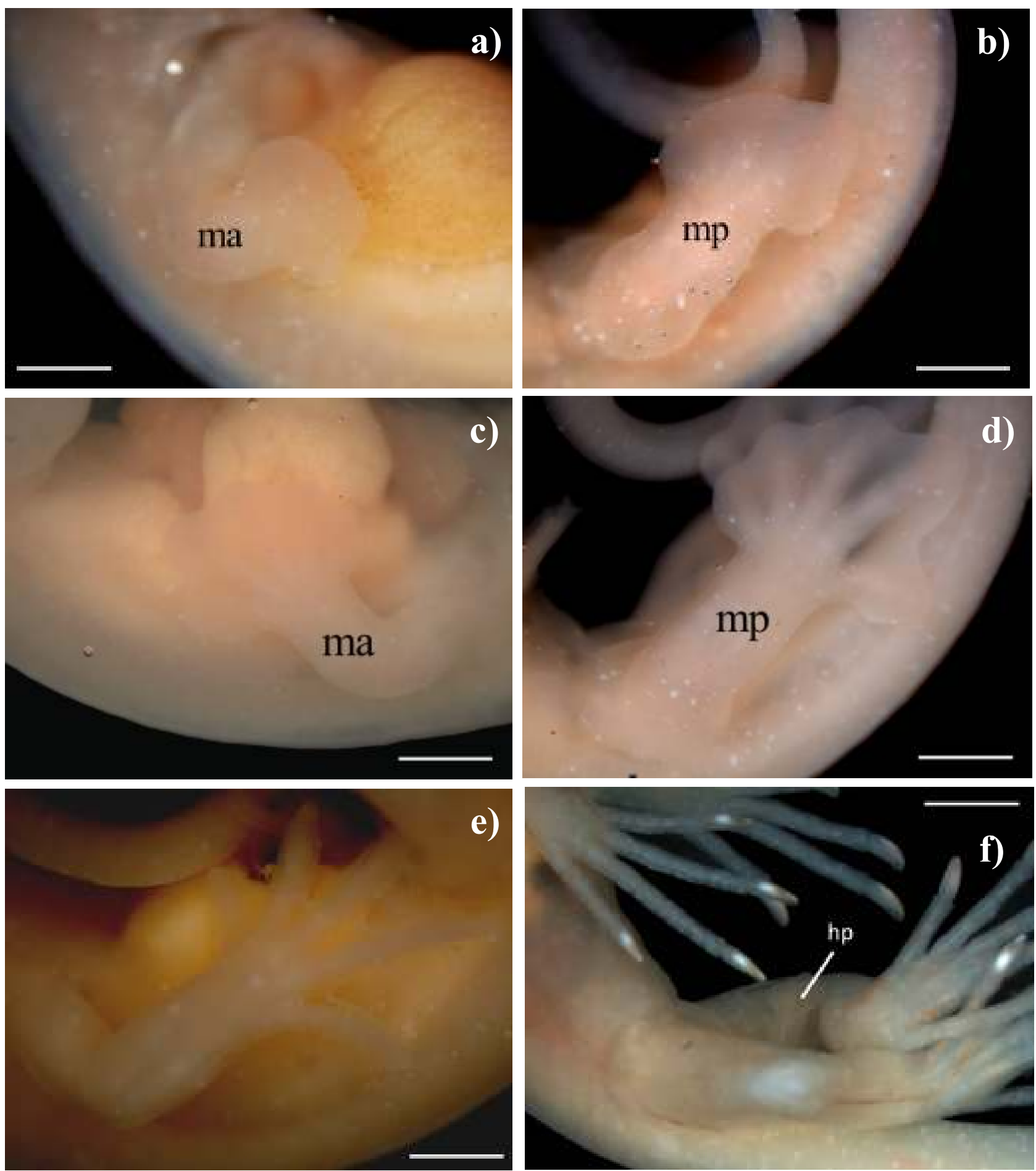
Estágio 13 (de 38 a 42 dias após a oviposição): crista mais evidente, prolongando-se da região occipital até a base da cauda do embrião. Primórdios de escamas visíveis sem a magnificação, dando aspecto rugoso à pele.

Estágio 14 (de 42 a 46 dias após a oviposição): pescoço totalmente formado e em sua porção lateral ocorrem dobras. Pela primeira vez aparece a escama modificada que é localizada abaixo do tímpano (escama subtimpânica). A crista estende-se até a ponta da cauda. Início da pigmentação ocorre na cauda, na forma de bandas levemente escuras, alternando-se com bandas sem pigmentação.

Estágio 15 (de 46 a 50 dias após a oviposição): escamas da região dorsal da cabeça estão completamente formadas e os lobos mesencefálicos não são mais visíveis. Os escudos nucais encontram-se mais esparsos e de maior tamanho.

Estágio 16 (de 50 a 56 dias após a oviposição): pigmentação do corpo se inicia. Pigmentos inicialmente encontram-se mais concentrados ao redor das cristas occipitais, dorsais e caudais.

Estágio 17 (de 56 a 62 dias após a oviposição): escudos nucais maiores e em maior número, distribuídos em 8 fileiras. Pálpebra completamente formada, porém as partes superior e inferior não se encontram unidas.

Estágio 18 (de 62 a 70 dias após a oviposição): há maior pigmentação com relação ao estágio anterior, e o embrião adquire o padrão de coloração do filhote. Pálpebra totalmente fechada. Há uma porção de vitelo ainda para ser consumido e o embrião está próximo da eclosão. 
Figura 7: fotos dos embriões de I. iguana nos estágios 13 a 18. Escala $=1 \mathrm{~cm}$.
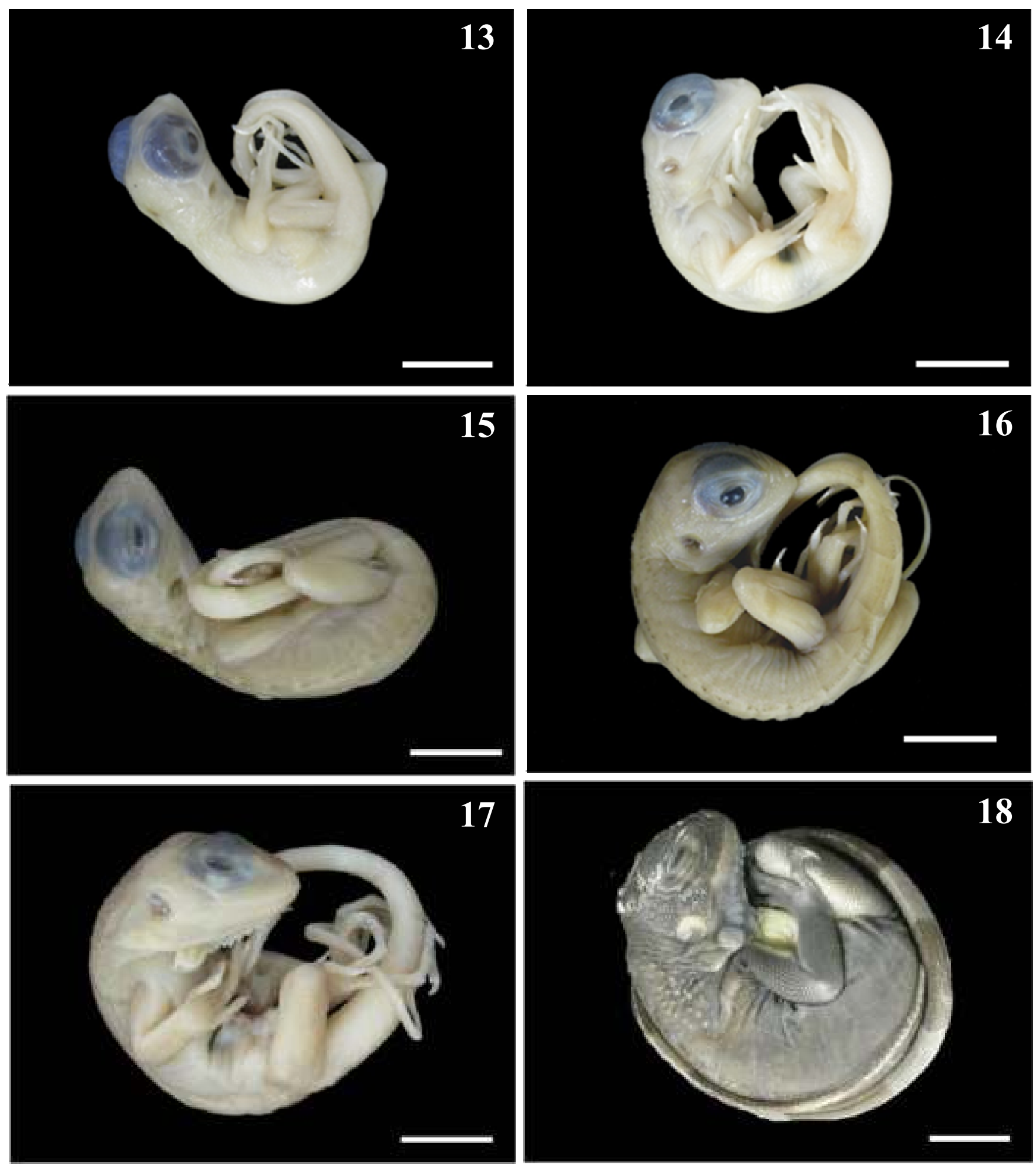
Figura 8: Detalhes dos lobos mesencefálicos e da glândula pineal no estágio 8 (a) das escleras ópticas no estágio 10 (b), da prega gular no estágio 11 (c), dos escudos nucais, no estágio 18 (d). No estágio 15 as escamas da cabeça estão completamente formadas (e) e em destaque (f) a escama modificada subtimpânica. Legenda: $\mathrm{ml}=$ lobos mesencefálicos, $\mathrm{pl}=$ pineal, eo = escleras ópticas, $\mathrm{pg}=$ prega gular, $\mathrm{em}=$ escama modificada (subtimpânica). Escala $=200 \mu \mathrm{m}$ em $a, b$ e $c$; Escala $=100 \mu \mathrm{m}$ em $d, e$ e $f$.
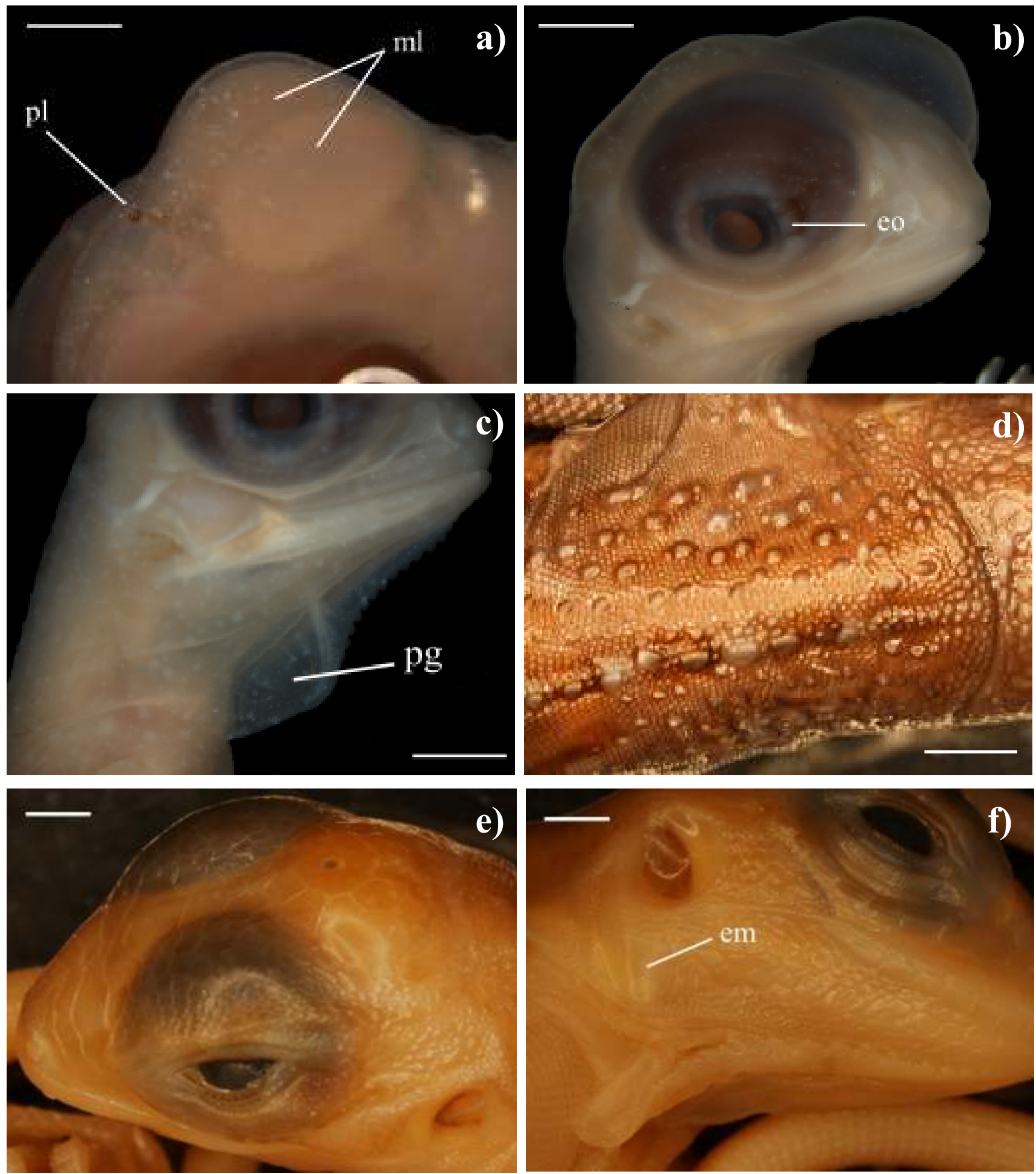
Tabela 1: Comparação dos estágios de I. iguana com estágios equivalentes propostos para diferentes espécies de lagartos:

\begin{tabular}{|c|c|c|c|c|c|c|c|}
\hline \multicolumn{5}{|c|}{ Iguania } & \multicolumn{3}{|c|}{ Scleroglossa } \\
\hline I. iguana & A. sagrei ${ }^{1}$ & A. impalearis ${ }^{2}$ & L. tenuis ${ }^{3}$ & C. versicolor ${ }^{4}$ & E. macularius ${ }^{5}$ & $P . p^{p i c t u s}{ }^{6}$ & L. vivipara ${ }^{7}$ \\
\hline 1 & 3 & 28 & 30 & 29 & 29 & 3 & 28 \\
\hline 2 & 4 & 29 & 31 & 30 & 29 & 4 & 30 \\
\hline 3 & 5 & 31 & 35 & 30 & 31 & & \\
\hline 4 & & 31 & 35 & & & 12 & \\
\hline 5 & 6 & 31 & 36 & $31-32$ & 31 & & 31 \\
\hline 6 & 8 & 33 & 37 & 34 & 32 & 12 & 32 \\
\hline 7 & 9 & 34 & & 35 & 34 & $14-20$ & 34 \\
\hline 8 & & 35 & 38 & 35 & 35 & & 35 \\
\hline 9 & 11 & 36 & 40 & 36 & 36 & & 36 \\
\hline 10 & 13 & 36 & & 37 & 37 & $22-28$ & 36 \\
\hline 11 & & & & 38 & & & \\
\hline 12 & 13 & & & & 37 & 30 & 37 \\
\hline 13 & 14 & 36 & & & & & \\
\hline 14 & 16 & 38 & & 39 & 40 & & 39 \\
\hline 15 & 15 & 39 & & & 41 & & \\
\hline 16 & 17 & 40 & 40 & 40 & & & \\
\hline 17 & & & & & & & \\
\hline 18 & 18 & 41 & $42-43$ & $41-42$ & 42 & 60 & 40 \\
\hline
\end{tabular}

Legenda: 1. Anolis sagrei (SANGER et al., 2008); 2. Agama impalearis (MOUDEN et al., 2000); 3. Liolaemus tenuis tenuis (LEMUS et al., 1981); 4. Calotes versicolor (MUTHUKKARRUPPAN et al., 1970); 5. Eublepharis macularius (WISE et al., 2009); 6. Paroedura pictus (NORO et al., 2009); 7. Lacerta vivipara (DUFAURE e HUBERT, 1961). 


\section{Discussão}

A Tabela de estágios embrionários de Iguana iguana contribui para a melhor caracterização de desenvolvimento dentro dos Iguania, em comparação e contraposição com os lagartos Scleroglossa, cuja espécie Lacerta vivipara é detalhadamente descrita em 40 estágios desde o início da segmentação, e aceita amplamente como referência (DUFAURE e HUBERT, 1961). No caso da espécie Lacerta vivipara (DUFAURE e HUBERT, 1961) todo o desenvolvimento é intrauterino. A maioria dos autores que estudaram espécies ovíparas iniciam suas tabelas com o número de estágio equivalente ao de L. vivípara, ou utilizam a característica principal para definir o estágio como em A. sagrei (SANGER et al., 2008), ou no caso $P$. pictus, definem os estágios baseados em intervalos regulares ao invés de basear-se no aparecimento de estruturas (vide correspondência de estágios na Tabela 1).

O desenvolvimento do embrião alcançado até o momento da oviposição varia entre as espécies (ANDREWS, 2004). Dessa forma o estágio do embrião de iguana logo após a oviposição pode ser comparado ao nível de desenvolvimento alcançado por L. vivipara no estágio 28. Similarmente, as espécies Agama impalearis e Eublepharis macularius, no momento da desova possuem embriões com desenvolvimento correspondente ao estágio 28-29 de L. vivípara (MOUDEN, 2000; WISE, 2009). Em Calotes versicolor a sequência de estágios pós-oviposição se inicia no estágio 29 (MUTHUKKARUPPAN et al., 1970) e em Liolaemus tenuis tenuis no estágio 30 (LEMUS et al., 1981). Comparativamente às demais espécies, oviposição em estágios mais iniciais de desenvolvimento são encontrados em A. sagrei, que pode ocorrer nos estágios correspondentes a 25 e 26 (SANGER et al., 2008), enquanto Paroedura pictus deposita embriões entre os estágios que correspondem ao 22 e 24 da tabela de L. vivipara (NORO et al., 2009).

A divisão de Squamata nos clados Iguania e Scleroglossa é baseada principalmente em caracteres morfológicos de natureza osteológica. A osteologia é a característica mais aplicável para relacionar Squamata fósseis e seus parentes viventes. Quatorze sinapomorfias distinguem o clado Iguania enquanto Scleroglossa é definido por vinte e quatro sinapomorfias (ESTES et al, 1988). Iguania e Scleroglossa possuem um ancestral comum, porém Scleroglossa se diversificou muito mais em 
relação à Iguania, que manteve muitas características do estado ancestral (VITT et al., 2003). Desta forma é possível que desde os eventos embriológicos diferenças quanto à ordem, tempo e taxa de desenvolvimento ocorram nos dois clados.

Os 18 estágios descritos para iguana podem ser distribuídos em três fases principais, utilizando como critérios características morfológicas bastante utilizadas pela literatura e que ocorrem em tempos e seqüências bem delimitados, que são o desenvolvimento dos arcos branquiais, dos membros e da pigmentação e escutelação. Devido à fragilidade do material embrionário, o manuseio para as descrições dos caracteres e as fotografias foram realizadas após a fixação. Porém este processo causa uma opacidade ao tecido o que inviabiliza a visualização e contagem de somitos, que é um critério também muito utilizado para as descrições de estágios. A taxa de formação de somitos é muito variável dentro dos répteis (HUBERT, 1985) e após certo tempo de desenvolvimento os somitos se desgastam e formam pequenos blocos de células mesodérmicas, assim como também ocorre um espessamento da epiderme, o que dificulta a individualização e contagem de cada somito, e que torna o somito um critério não consistente (CHAN et al., 2005).

Em iguana, a fase inicial ocorre entre os estágios 1 e 4 , as característicaschave são os arcos branquiais, a vesícula óptica e as vesículas cerebrais; a fase intermediária, entre os estágios 5 a 9, cuja característica-chave é o desenvolvimento dos brotos dos membros (a partir da formação do autopódio até a formação das garras) e dos processos maxilares e mandibulares; e a fase final, em que as principais características são as características espécie-específicas, formação das escamas e pigmentação, entre os estágios 10 a 18 .

A comparação de tabelas de estágios embrionários entre espécies é dificultada devido a diversos fatores como a descrição de formas ovíparas e vivíparas. No caso das espécies ovíparas, pode ocorrer ainda uma variação no nível de desenvolvimento do embrião no momento da desova, como explicitado anteriormente, a temperatura de incubação dos ovos, os critérios para classificação de estágios e diferença no número de estágios descritos, que entre as tabelas comparadas neste estudo varia de 14 a 18 estágios. No entanto, é possível comparar os eventos e a duração das fases principais que determinam o desenvolvimento dos arcos e fendas branquiais, membros, pigmentação e escutelação. Estas características-chave parecem ser bastante conservadas nos dois clados. Observa-se que em todos os casos ocorre uma 
sobreposição do final da segunda fase com o começo da terceira. Variações no tempo de duração das fases ocorrem dentro dos dois grupos, indicando que pode haver alguma relação mais ao nível de família ou de espécie com relação às heterocronias e diferenças estruturais.

A heterocronia é um processo evolutivo (SMITH, 2003) e um tipo comum entre os tetrápodas é a que ocorre nos membros (BININDA-EMONDS, 2007). O padrão de formação dos membros é um dos critérios principais para se determinar os estágios de lagartos e dada a importância que a heterocronia tem explicitado em contextos filogenéticos, o grupo Squamata se apresenta como uma interessante fonte de investigação. Em iguana é visível a diferença no tempo de desenvolvimento dos membros, já que é possível determinar em determinado estágio que os membros anteriores estão maiores que os posteriores. O mesmo padrão é descrito para as espécies E. macularis e L. tenuis tenuis, respectivamente representantes das famílias Gekkonidae, do clado Scleroglossa e Iguanidae, do clado Iguania. O padrão reverso, dos brotos dos membros posteriores se apresentarem maiores que os anteriores em determinados estágios ocorrem nas espécies A. impalearis e A. sagrei, pertencentes aos grupos Agamidae e Iguanidae, respectivamente, ambos do clado Iguania. Dessa forma, dentro do grupo dos iguanídeos podemos encontrar dois tipos de padrão, seja o broto do membro anterior maior que o posterior quanto o padrão ao revés. Em serpentes apenas um estudo (BOUGHNER et. al, 2007) menciona o desenvolvimento de brotos de membros dado o pequeno número de espécies estudadas. Este estudo identifica a formação do broto do membro posterior rudimentar na espécie Python sebae.

Os dados de Squamata não revelam uma tendência clara para a formação dos membros diferentemente do que ocorre em quelônios, no qual a tendência é a do desenvolvimento do membro anterior ocorrer primeiro com exceção das tartarugas marinhas, em que o desenvolvimento dos membros anteriores e posteriores é sincrônico (MILLER, 1985). Nos crocodilianos as espécies Caiman latirostris (IUNGMAN et al., 2008) e Caiman porosus (MAGNUSSON e TAYLOR, 1980) possuem o padrão reverso ao do crocodiliano pertencente a família Alligatoridae Alligator mississipiensis (FERGUSON, 1985). Assim, elaborar tabelas de estágios de mais espécies dos grupos Iguania e Scleroglossa (incluindo principalmente serpentes com presença de membros rudimentares durante o desenvolvimento embrionário e 
lagartos que apresentam redução intermediária ou completa de membros) podem evidenciar alguma tendência de desenvolvimento dos membros do grupo Squamata.

A partir da comparação dos eventos de cada estágio de iguana com os respectivos estágios nas demais espécies (Tabela 1 do apêndice) é possível detectar diferentes taxas de desenvolvimento e ordem de eventos. Em C. versicolor, a fissura coróide se fecha antes, e tanto a pineal quanto a pigmentação aparecem primeiro. Em A. impalearis o desenvolvimento dos processos maxilares e mandibulares é mais rápido enquanto a pigmentação do olho é mais tardia. L. tenuis tenuis que também é um iguanídeo, tem início de pigmentação anterior à Iguana. Quanto à formação dos olhos, o início da formação das pálpebras ocorre anteriormente em L. vivipara e E. macularius. A pigmentação do olho pode ocorrer de diferentes formas, como por exemplo, em iguana, os pigmentos aparecem inicialmente em direção perpendicular a fissura coróide na porção mediana do olho; em A. impalearis se inicia como um anel; e em $P$. pictus se inicia na região superior da retina se estendendo em seguida para a região inferior.

Estas diferenças entre as espécies não é consistente com os grupos a que pertencem. Esta falta de relação pode ser resultante do fato que a divisão entre Iguania e Scleroglossa é baseada em características morfológicas, cuja maioria é de sinapomorfias de estruturas ósseas (ESTES et al., 1988). A sequência de desenvolvimento do processo condrogênico pode ser útil para comparações e detecção de alteração de padrão ósseo (MÜLLER, 1991) mas somente pode ser visualizada através de técnicas específicas, como diafanização e coloração dos ossos por alizarina e das cartilagens pelo azul de alcian, (DAVIS e GORE, 1936; DINGERKUS e UHLER, 1977). A divisão entre os dois clados não é corroborada por análises moleculares (VIDAL e HEDGES, 2005), e como as heterocronias estão relacionadas com mecanismos de expressão de genes, este pode ser mais um motivo da falta de relação encontrada neste estudo

A comparação de tabelas de estágios embrionários auxilia o reconhecimento de processos heterocrônicos e diferenças estruturais. Após a identificação destes processos é possível formular hipóteses sobre as mudanças genéticas e morfológicas ao longo da evolução (SMITH, 2003; BOUGHNER et al., 2007). Em I. iguana, as maiores diferenças são encontradas a partir do estágio 10, com o desenvolvimento de características específicas como a formação da prega gular, escudos nucais e das 
cristas. A tabela de iguana se aproxima à de $A$. sagrei, tanto em número de estágios quanto à proximidade de ordem de aparecimento de estruturas e pode ser dividida em três fases principais de acordo com critérios bastante utilizados em demais tabelas embrionárias. 


\section{Capítulo II}

\section{Excreção de nitrogênio em embriões de Iguana iguana}

\section{Abstract}

In a closed system such as the cleidoic egg of birds and reptiles, storage of nitrogenous wastes occurs during the embryonic development, and ammonia raised from protein catabolism is converted to urea or uric acid due its toxicity. Eggs of the lizard Iguana iguana were used for determination of nitrogen excretion pattern during embryonic development, and after hatching. The nitrogen concentration and content of each nitrogenous residue was measured in the allantois, whole egg, and in blood of hatchlings and adults. Urea concentration was higher and represented $82 \%$ of the 11,3 $\mathrm{mg}$ of nitrogen accumulated inside the egg at the end of incubation, while uric acid $17 \%$ and ammonia $1 \%$ respectively. The significative rise in urea concentration, at 55 days matched with concomitant increase in egg mass due to water absorption. Urea accumulated in the allantois rather than distributed through the whole egg. Urea was also the major nitrogen waste in hatchlings of 7 days, while in adults it was uric acid.

\section{Resumo}

Em um sistema fechado, como o ovo cleidóico dos répteis e aves, ocorre acúmulo de excretas nitrogenados ao longo do desenvolvimento embrionário. A amônia, proveniente do catabolismo de proteínas, dada a sua toxicidade, deve ser convertida em uréia ou ácido úrico. Ovos do lagarto Iguana iguana foram usados para determinação do padrão de excreção ao longo do desenvolvimento embrionário e após a eclosão. Para isso foram medidos a concentração e conteúdo de nitrogênio de cada resíduo nitrogenado no alantóide, no ovo homogenizado, e no sangue de filhotes recém-eclodidos e adultos. Nos ovos, a concentração de uréia foi maior que os demais resíduos durante todo o período embrionário, representando $82 \%$ dos $11,3 \mathrm{mg}$ de nitrogênio acumulados ao final da incubação pelo ovo, enquanto o ácido úrico 
representou $17 \%$ e a amônia $1 \%$. A uréia foi acumulada no alantoide, não possuindo distribuição homogênea dentro do ovo, como os demais resíduos. O aumento significativo da concentração de uréia foi coincidente com o aumento significativo em massa dos ovos devido à absorção de água. Filhotes de 7 dias apresentaram predominância de produção de uréia e adultos de ácido úrico.

\section{Introdução}

O ovo amniótico foi uma etapa importante para a conquista definitiva da vida terrestre, possibilitando independência do ambiente aquático para a reprodução (PACKARD, 1966). No entanto, um dos maiores desafios para o desenvolvimento do ovo no ambiente terrestre é a excreção de resíduos nitrogenados e a manutenção do balanço hídrico. Os principais produtos finais do metabolismo das proteínas são amônia, uréia e ácido úrico, sendo que a excreção do metabólito esta geralmente eorrelacionada com a disponibilidade de água no ambiente (PACKARD, 1966), toxicidade e custos de produção (WRIGTH, 1995).

A amônia é altamente tóxica quando em concentração elevada, assim, alguns animais a convertem em compostos menos tóxicos como uréia e ácido úrico. Na fase embrionária, que em répteis e aves ocorre dentro de um ovo amniótico, o alantóide tem a função de armazenar os excretas nitrogenados resultantes do metabolismo das proteínas (ROMER, 1957), além de ser considerado atuante na osmorregulação (VLECK, 1991). Como o ovo acumula os excretas por um longo período até a eclosão, um composto menos tóxico é supostamente necessário para o desenvolvimento e a sobrevivência do embrião dentro do ovo (PORTER, 1972). O acúmulo de excreta nitrogenado também está relacionado com o balanço hídrico dos ovos, pois quanto maior a quantidade de água dentro do ovo, mais diluído são as concentrações e menor o risco de toxicidade do excreta, como demonstrado nos trabalhos de Packard e Packard (1987 e 1989).

A excreção de nitrogênio em ovos de aves foi considerada por muito tempo uma recapitulação da evolução, devido ao trabalho de Needham (1931), que mostrava ao longo da incubação alterações da produção de amônia para uréia, e em seguida, para ácido úrico. Anos depois com o trabalho de Fisher e Eakin (1957), foi demonstrado 
que os três principais compostos nitrogenados estavam presentes desde o início do desenvolvimento embrionário. Em ovos de répteis, um modelo menos estudado que o de aves, também foi proposto uma alteração na excreção de uréia para ácido úrico durante o final da incubação ou após a eclosão como um mecanismo de evitar a toxicidade do acúmulo de uréia (CLARK, 1953) ou para adaptação para a vida fora do ovo (PACKARD, 1966).

O objetivo deste trabalho foi determinar o tipo de resíduo nitrogenado que é excretado durante o período de desenvolvimento embrionário e após a eclosão do lagarto Iguana iguana. A questão central foi evidenciar eventuais alterações qualitativas e quantitativas na produção de excretas e suas possíveis relações hídricas, dado que o ovo possui casca pergaminácea e espécie aumenta em massa pela absorção de água do meio.

\section{Material e Métodos}

\subsection{Obtenção dos ovos}

Os ovos foram coletados de uma colônia de iguana mantidos em cativeiro, em um criadouro científico mantido no Campus da UNESP de Rio Claro, durante a estação reprodutiva de 2009 e 2010, entre os meses de setembro e outubro. Cada ovo foi numerado e colocado em caixas plásticas (38 cm comprimento, $28.5 \mathrm{~cm}$ de largura, e $6.5 \mathrm{~cm}$ de altura), parcialmente cobertas com vermiculita úmida. As caixas foram mantidas em uma câmara climática (Eletrolab EL011), a temperatura constante de $30^{\circ}$ $\mathrm{C}\left( \pm 0,1^{\circ} \mathrm{C}\right)$, que é a temperatura ideal para a incubação de ovos de iguana (LICHT e MOBERLY, 1965). Os ovos foram vistoriados semanalmente para conferir sua viabilidade, desenvolvimento e o nível de umidade da vermiculita.

\subsection{Excreção de nitrogênio nos embriões}

Para a determinação dos excretas nitrogenados armazenados no interior dos ovos duas diferentes técnicas foram utilizadas: I) amostras do alantóide $(\mathrm{n}=48)$, e II) amostras de ovos homogeneizados $(n=18)$. Para o desenho experimental amostras foram tomadas de ovos de diferentes ninhadas inicialmente aos 25 dias de incubação e depois um ponto amostral a cada 10 dias até a eclosão, que ocorreu 
entre 75-85 dias. Não foram tomadas amostras antes dos 25 dias devido à incompleta formação das membranas extra-embrionárias, e ao critério adotado inicialmente de isolar o conteúdo do alantóide. Em 2009, o tempo de incubação foi mais longo que o usual, e as amostras estenderam até os 85 dias.

A cada ponto amostral, oito ovos foram pesados (Owa Labor; $\pm 0,01 \mathrm{~g}$ ), e colocados em uma câmara fechada preenchida com dióxido de carbono, por aproximadamente uma hora, para assegurar a morte do embrião. Em seguida, os ovos foram abertos, os diferentes componentes (alantóide, vitelo, membranas, casca e embrião foram separados e pesados. Amostras do alantóide foram separadas para análises que foram realizadas no mesmo dia. Dois ovos extras foram homogeneizados e centrifugados (como descrito em PACKARD et al, 1983), e a fração líquida foi utilizada para a detecção de excretas nitrogenados no ovo inteiro.

Amostras do alantóide e do homogeneizado foram analisadas em duplicata para uréia e ácido úrico por kits enzimáticos colorimétricos comerciais (Ácido úrico Liquiform LABTEST e Uréia CE LABTEST). Para a determinação de amônia uma modificação da técnica de Verdouw et. al. (1977) foi utilizada, que inclui a adição de $400 \mu \mathrm{L}$ de ácido tricloro-acético para cada $100 \mu \mathrm{L}$ da amostra do alantóide antes de proceder à centrifugação.

Para a determinação de uratos insolúveis, seis ovos próximos à eclosão foram homogeneizados em um liquidificador (Vithory) com a adição de $25 \mathrm{~mL}$ de água destilada. O homogeneizado foi centrifugado (FANEM Baby 206) por 10 minutes a $4000 \mathrm{rpm}$ e o sobrenadante foi transferido para um frasco volumétrico. O decantado foi ressuspenso em $25 \mathrm{~mL}$ de carbonato de lítio $(0.1 \mathrm{~N})$ e deixado por três horas a temperatura ambiente para dissolver o ácido úrico. Em seguida foi realizada uma nova centrifugação e o sobrenadante obtido foi diluído para completar o volume de $50 \mathrm{~mL}$ (PACKARD et al, 1983). As amostras foram analizadas com o kit colorimétrico enzimático para ácido úrico (Liquiform, LABTEST).

As concentrações dos ensaios enzimáticos foram determinadas utilizando um espectrofotômetro (FEMTO 600 Plus) a $600 \mathrm{~nm}$ para amônia e uréia, e $550 \mathrm{~nm}$ para ácido úrico. Curvas padrão foram utilizadas para confirmar a relação linear entre concentração e absorbância. O conteúdo total de nitrogênio-amônia, nitrogênio-uréia e nitrogênio-ácido úrico no alantóide foi calculado pela multiplicação da concentração do excreta pelo volume do alantóide. Para cálculos da técnica de 
homogenização o volume do ovo foi calculado multiplicando-se a massa pelo fator 1,05 de acordo com Tracy et. al. (1978).

\subsection{Excreção de nitrogênio em iguanas filhotes e adultos}

Amostras de sangue foram coletadas de filhotes com sete dias, antes de sua primeira alimentação. Dez iguanas (massa $=9,67 \pm 0,15 \mathrm{~g}$ ) foram mortos por decapitação para a coleta do sangue. O sangue foi imediatamente centrifugado (Sanyo MSE) por três minutos em $13000 \mathrm{rpm}$ para coleta d plasma, que foi analisado utilizando os mesmos procedimentos para as amostras de alantóide. Para os iguanas adultos (massa $=1,87 \pm 0,18 \mathrm{Kg} ; \mathrm{n}=10$ ) amostras de sangue de $2 \mathrm{~mL}$ foram coletadas por punção da veia caudal. O sangue foi centrifugado (Sigma) para coleta de plasma para as análises.

\subsection{Análises estatísticas}

A significância aparente nas concentrações medidas de excretas nitrogenados entre os estágios de desenvolvimento foi analisada utilizando ANOVA de uma via, e para testes pareados posteriores foi utilizado o teste de Student Newman Keul's. Para conteúdo de nitrogênio e aumento em massa dos ovos e embriões, o teste utilizado foi o ANOVA em ranks, seguido de teste post-hoc de Dunn. Para comparação das médias de concentrações de uréia entre o alantóide e o ovo homogeneizado foi utilizado o teste de Mann-Whitney. Para comparações entre filhotes e adultos uma ANOVA de duas vias foi utilizada, com idade e tipo de excreta nitrogenado como fatores. Todas as análises foram conduzidas pelo pacote estatístico Sigma Plot versão 11.0, ao nível de confiança de 95\% $(\mathrm{P}=0,05)$. Todos os resultados são apresentados na forma de média \pm erro padrão.

\section{Resultados}

\subsection{Aumento em massa dos ovos e embriões}

A massa inicial dos ovos foi de $15,65 \mathrm{~g}( \pm 0,07)$ e ao longo da incubação os ovos absorveram uma média de 17,85 g $( \pm 1,67)$ de água do meio circundante, resultando ao final da incubação em ovos de massa com média de of 33,5 g $( \pm 1,67)$, 
o que corresponde a um aumento de $116 \%$. A massa do embrião no primeiro período do experimento, aos 25 dias de incubação, foi de média de $0,90 \mathrm{~g}( \pm 0,09)$ e ao final do experimento, quando o embrião estava próximo da eclosão, a massa foi de 10,07 $\mathrm{g}( \pm 0,35)$, e este aumento correspondeu a $123 \%$, e graficamente apresenta padrão exponencial (Figura 1).

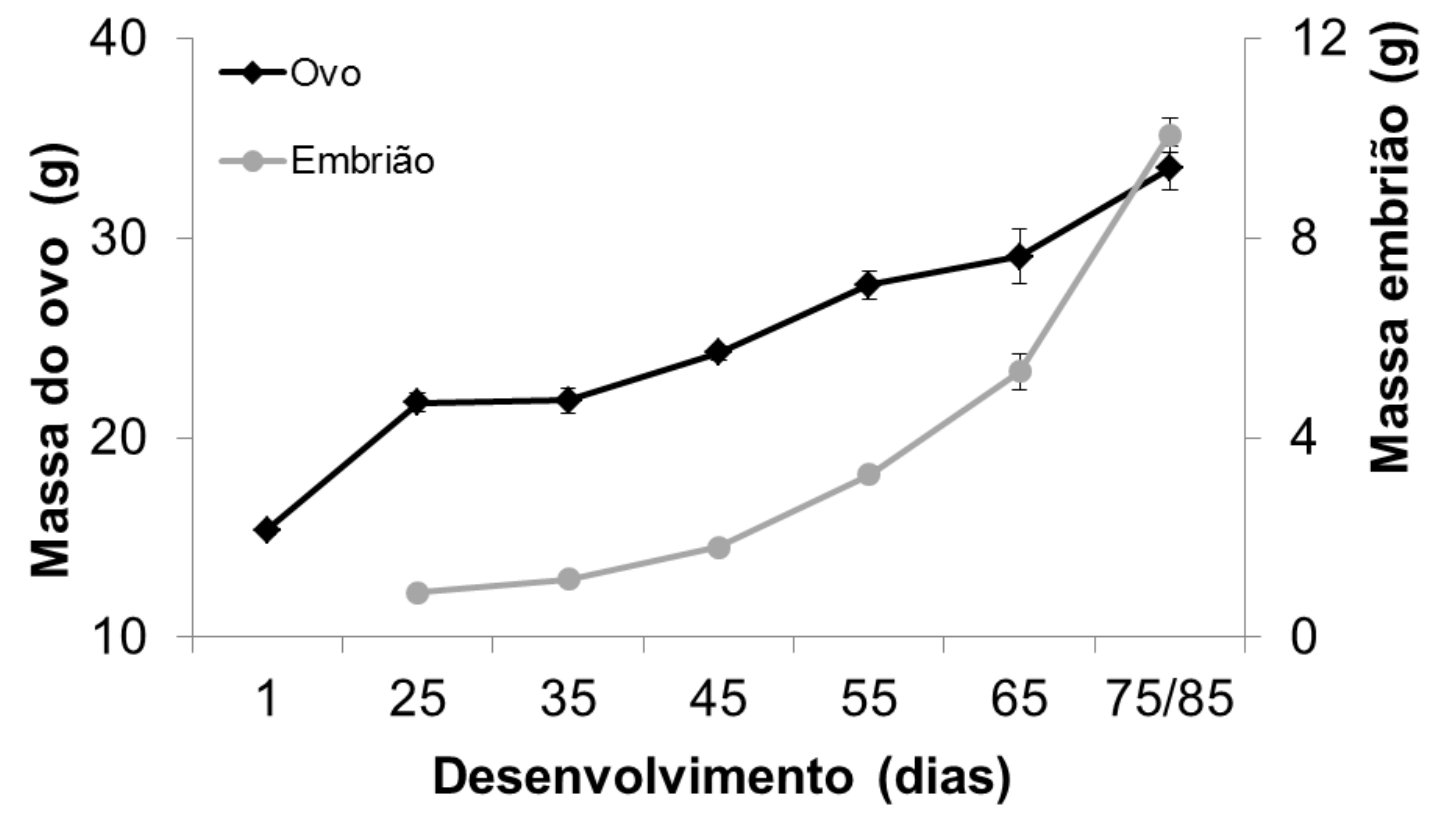

Figura 1: Aumento em massa (média \pm erro padrão) de ovos a partir da data de desova (dia 1) e embriões a partir de 25 dias, até o final do período de incubação. A massa dos ovos e dos embriões foram estatisticamente diferentes dos respectivos valores iniciais a partir de 55 dias (Anova on Ranks e teste de Dunn, $\mathrm{P}<0,05$ ).

\subsection{Concentração e conteúdo de nitrogênio dos excretas}

O excreta nitrogenado predominantemente armazenado no alantóide foi a uréia, encontrado em maior concentração durante todo o período de incubação (Figura 2). A uréia atingiu o valor máximo de concentração aos 55 dias, com uma média de $129,25 \mathrm{mg} / \mathrm{dL}( \pm 13,83)$ ou 21,46 mM $( \pm 2,30)$. A análise do ovo homogeneizado apresentou uma menor concentração de uréia $(4,30 \pm 1,11 \mathrm{Mm}$ aos 55 dias) que no alantóide (Figura 3; teste de Mann-Whitney, $\mathrm{P}=0,002$ ), mas as concentrações de amônia e ácido úrico foram similares nas duas técnicas. Uma fraca correlação positiva entre a concentração do alantóide e homogeneizado foi encontrada para 
amônia $\left(\mathrm{R}^{2}=0,056, \mathrm{P}=0,045\right)$. Não foi encontrada correlação para uréia $\left(\mathrm{R}^{2}=\right.$ $0,239, \mathrm{P}=0,431)$ ou ácido úrico $\left(\mathrm{R}^{2}=-0,414, \mathrm{P}=0,160\right)$.

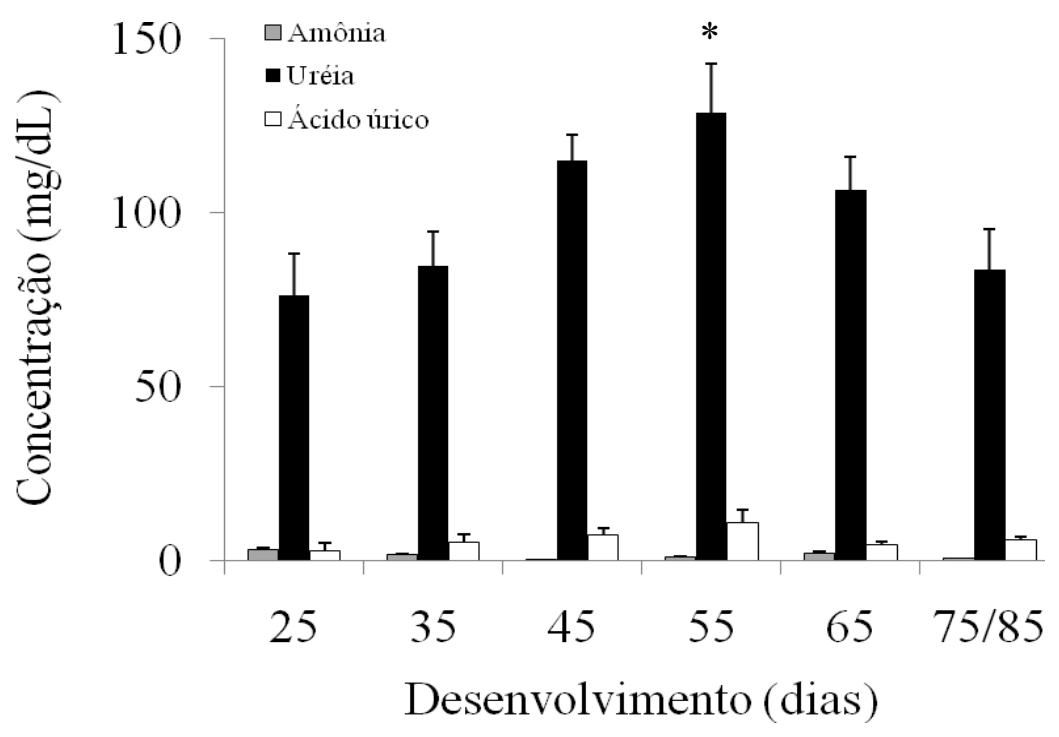

Figura 2: Concentração em $\mathrm{mg} / \mathrm{dL}$ dos diferentes metabólitos de nitrogênio presentes no alantóide (média \pm erro padrão). O símbolo denota diferença estatística com relação ao valor inicial (Anova de uma via e Student NewmanKeuls; $\mathrm{P}<0,05)$.

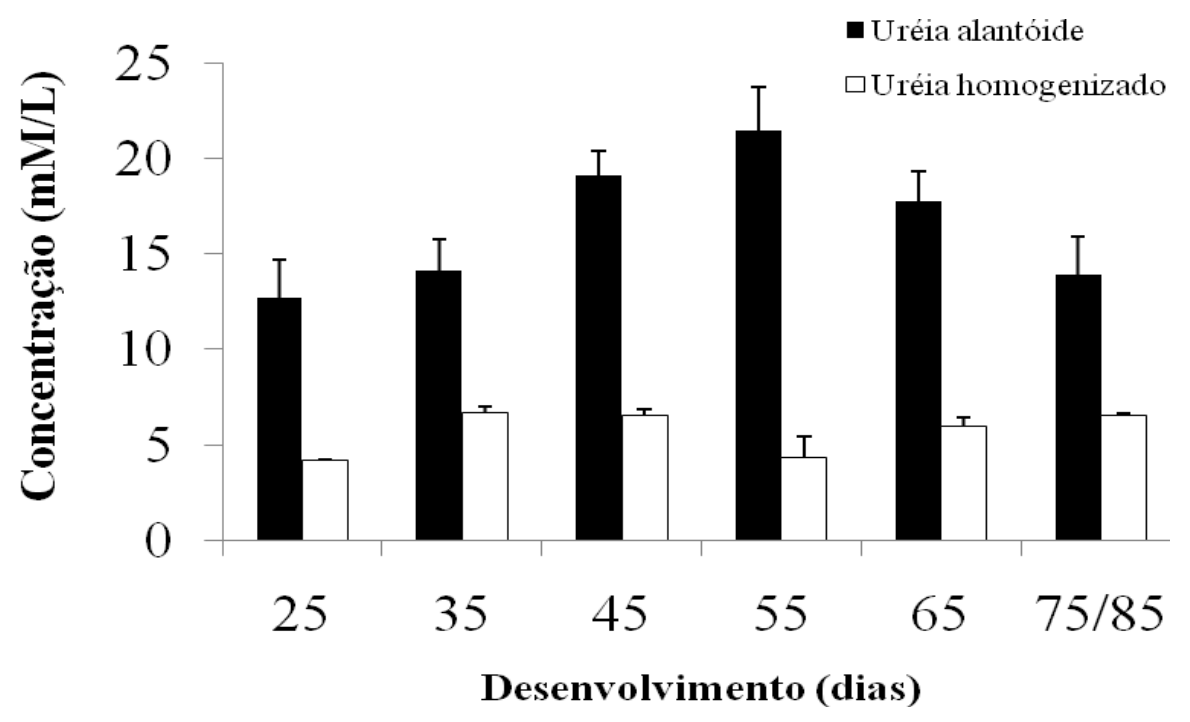

Figura 3: Concentração de uréia (média \pm erro padrão) calculado em $\mathrm{mmol} \cdot \mathrm{L}^{-1}$ no alantóide e no ovo inteiro. A concentração de uréia encontrada no alantóide e no ovo homogeneizado foram significativamente diferentes (Mann-Whitney, $\mathrm{P}=0,002)$. 
$\mathrm{O}$ conteúdo de $\mathrm{N}$-amônia, $\mathrm{N}$-uréia e $\mathrm{N}$-ácido úrico foram calculados com base no peso molecular proporcional do nitrogênio, e os valores estão expressos na Figura 4. Um total médio de $11,25 \mathrm{mg}( \pm 0,79)$ de nitrogênio foi armazenado no alantóide ao final da incubação, e aproximadamente $82 \%$ do total de nitrogênio nos ovos está na forma de uréia, enquanto amônia e ácido úrico representam 1 e 17\% respectivamente.

Comparando-se com o valor inicial, o conteúdo de nitrogênio-uréia é significativamente elevado aos 55 dias $(\mathrm{P}<0,05)$, mas continua em um nível constante até o final da incubação enquanto os outros compostos permanecem constantes durante todo o desenvolvimento. Ao calcular o conteúdo proporcional de nitrogênio em relação à massa em grama do embrião, o gráfico mostra um declínio conforme o tempo de incubação, mas isso ocorre devido ao aumento exponencial do embrião.

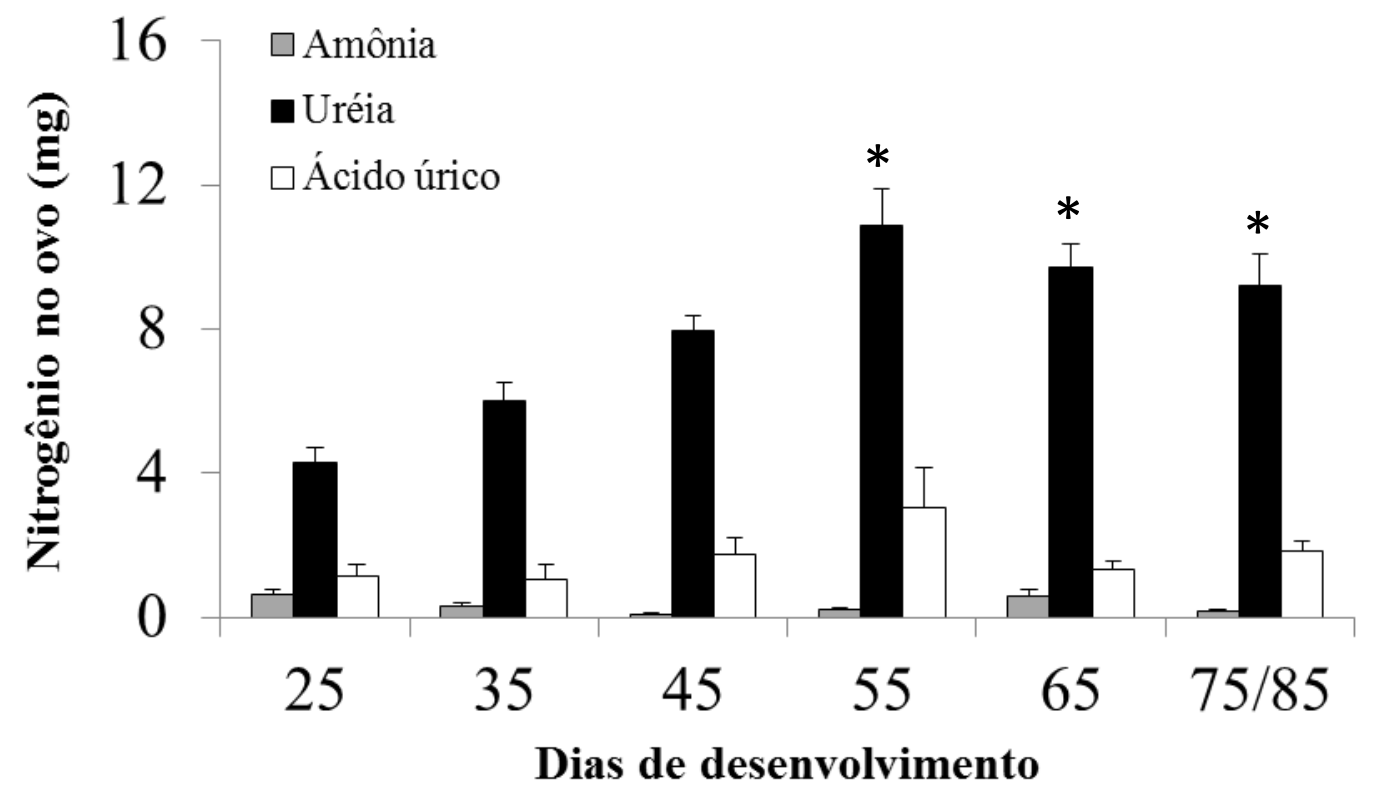

Figura 4: Conteúdo de nitrogênio ( $\mathrm{mg}$ ) no ovo em relação aos dias de desenvolvimento (média \pm erro padrão). O símbolo denota diferença estatística em relação ao valor inicial de 25 dias (Anova on Ranks e Dunn's, $\mathrm{P}<0,05$ ). 


\subsection{Filhotes e adultos}

O sangue dos filhotes de sete dias e dos iguanas adultos mostrou que há mudança no padrão de excreção ao longo da ontogenia. Filhotes apresentaram maiores concentrações de uréia que adultos $(19,90 \pm 1,56$ e $4.55 \pm 0,16 \mathrm{mg} / \mathrm{dL}$ respectivamente) e menores concentrações de ácido úrico $(2,06 \pm 0,21$ e 7,63 $\pm 0,31$ $\mathrm{mg} / \mathrm{dL}$ ). Concentração de amônia não foi diferente entre filhotes e adultos (Figura $5)$.

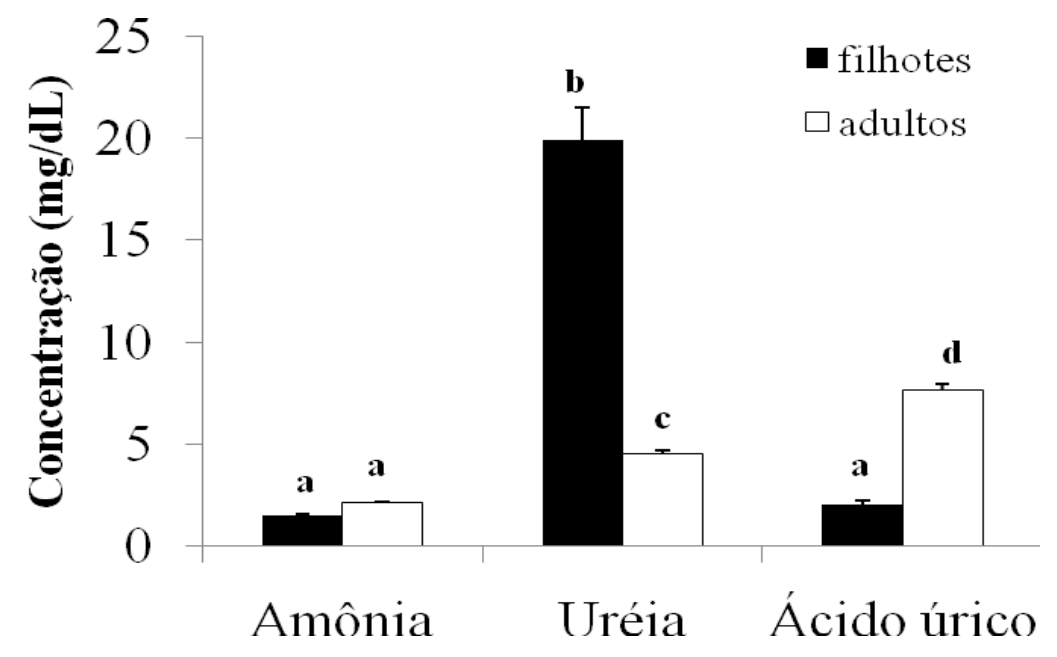

Figura 5: Concentração de excretas nitrogenados no sangue de filhotes recémeclodidos e iguanas adultos (média \pm erro padrão). Filhotes apresentaram maiores valores de uréia enquanto adultos apresentaram valores maiores para ácido úrico (Anova de duas vias; $\mathrm{P}<0,05$ ).

\section{Discussão}

A uréia foi o produto de excreção predominantemente encontrado durante todo o período de incubação em embriões de I. iguana. Até o momento, o iguana foi o único lagarto estudado para a determinação da excreção de nitrogênio durante a fase embrionária. Porém, a ureotelia foi relatada para embriões de outras espécies de répteis, como as serpentes Coluber constrictor constrictor (CLARK, 1953; PACKARD e PACKARD, 1987), Thamnophis s. sirtalis (CLARK e SISKEN, 1956) 
e duas espécies do gênero Psammophis (HAGGAG, 1964). Dentre quelônios as espécies Trionyx spiniferus (PACKARD e PACKARD, 1983), Chelidra serpentina (PACKARD et al., 1984) e Terrapene ornata (PACKARD et al., 1985) também apresentam ureotelia. A única exceção ao padrão ureotélico é o crocodiliano, Alligator mississipiensis, que excreta ácido úrico e uréia em proporções similares (CLARK et al., 1957).

Os filhotes recém-eclodidos de iguana também apresentaram predominância de uréia como produto da excreção, diferentemente das serpentes do gênero Psammophis em que os embriões eram ureotélicos, mas os filhotes apresentaram uma grande produção de ácido úrico dois dias após a eclosão (HAGGAG, 1964). Em ovos da serpente Coluber c. constrictor foi relatado que a formação de uréia decai ao final da incubação enquanto a produção de ácido úrico aumenta proporcionalmente (CLARK, 1953). A predominância de uréia nos filhotes de iguana recém-nascidos pode ser decorrente do uso do vitelo remanescente na cavidade abdominal como fonte de energia.

O presente estudo evidencia que a uréia é armazenada no alantóide e que a amônia e o ácido úrico estão distribuídos em concentrações similares por todos os compartimentos do ovo. Fisher e Eakin (1957) e Clark (1953) encontraram estas mesmas distribuições de excretas nitrogenados em ovos de galinha e de serpentes, respectivamente. Packard (1966) sugere que a albumina presente no alantóide é uma reserva para excretas nitrogenados e água, e Vleck (1991), que o alantóide seria um órgão responsável pela osmorregulação. A uréia é um composto osmoticamente ativo (OPIE, 1965) e sua concentração elevada no alantóide pode ser uma evidência de que seja uma molécula atuante na manutenção do equilíbrio osmótico entre o ambiente interno do ovo e o ambiente externo.

Os ovos flexíveis de I. iguana aumentaram 2,14 vezes em massa durante o período de incubação devido à absorção de água do meio. Absorção de água por ovos de répteis foi bem documentado em muitos estudos (e.g. CUNNINGHAM e HURWITZ, 1936; TRACY, 1980; PACKARD et al., 1981; THOMPSON, 1987). O mecanismo para absorção de água é dependente da existência de um gradiente de potencial hídrico entre o ovo e o meio. Ovos de répteis podem realizar trocas de água com o seu meio circundante na forma de vapor e líquida (PACKARD e PACKARD, 1988), e assim a troca total resultante depende da condutividade 
hidráulica e da condutividade de vapor de água do meio (ACKERMAN, 1991). As propriedades hidráulicas do meio variam em função do potencial hídrico, que dirige o transporte de água líquida e determina a direção de seu fluxo. Assim, um substrato com alto potencial hídrico geralmente proporciona uma absorção de água aos ovos no decurso da incubação, que, consequentemente, aumentam em massa (PACKARD, 1991).

A hipótese atual é de que embriões que se desenvolvem em ambientes úmidos irão absorver mais água para dentro dos ovos, diluindo sua concentração de uréia (PACKARD et al., 1984). Esta pode ser a razão pela qual a concentração de uréia permaneceu constante nos ovos de iguana desde 55 dias até o final da incubação, apesar do embrião continuar a crescer e metabolizar, gerando resíduos nitrogenados. Assim, apesar da quantidade de nitrogênio na forma de uréia aumentar em 2,5 vezes, o incremento da concentração foi de apenas 1,7 vezes, em relação ao valor inicial medido aos 25 dias. Desta forma, a concentração de uréia não passou de 0,20 mM, um valor muito abaixo do limite mínimo de toxicidade de $26 \mathrm{mM}$ em mamíferos (HAND e SOMERO, 1972). A maioria dos estudos até o momento enfatizou a possibilidade dos efeitos tóxicos da uréia, como em estudos com tartarugas incubadas em ambientes secos (PACKARD e PACKARD, 1989; PACKARD et al., 1985). Porém, no presente estudo, em que os ovos foram incubados em meio de alto potencial hídrico, a questão estaria relacionada com a diluição dos fluidos e com a osmolaridade dela resultante. Tentativas de determinação da osmolaridade do fluido do alantóide de iguanas foram realizadas utilizando o método de ponto de congelamento. Todavia, dado a elevada quantidade de albumina presente no fluido, que aumenta a pressão osmótica coloidal (BRICKER, 2004), o método não se revelou adequado.

O exame da literatura pertinente revela que foram poucas as espécies de répteis estudadas no tocante à questão da excreção de nitrogênio na fase embrionária. Assim, não é possível relacionar a natureza do produto excretado ao tipo de casca dos ovos dos répteis, porém algumas evidências podem ser destacadas. Crocodilianos, que possuem ovos com casca de carbonato de cálcio na forma de calcita, muito rígida e similar ao das aves, excretam proporções similares de uréia e ácido úrico, sendo de 44\% e 50\% respectivamente (CLARK et al.,1957). Estes ovos possuem pequena troca de água com o meio, mas possuem uma grande quantidade 
de albumina, que armazena água para dar suporte ao desenvolvimento dos embriões (PACKARD, 1983). Em três espécies de quelônios, de três de serpentes e no lagarto iguana, que possuem ovos com casca variando em composição de calcárea a pergaminácea, excretam predominantemente uréia, variando de 70 a $83 \%$ do total de produtos nitrogenados (PACKARD e PACKARD, 1983, 1987; PACKARD et al, 1984, 1985; HAGGAG, 1964, presente estudo). Desta forma, o tipo de casca parece não ter influencia no resíduo nitrogenado formado e a ureotelia poderia ser uma condição sinapomórfica em répteis.

Todavia, os Squamata representam um grupo bastante diversificado e de grande valência ecológica e seria necessário o estudo de um maior espectro de espécies para tentar se estabelecer as eventuais alterações da produção de uréia e de ácido úrico ao longo do desenvolvimento embrionário e através da ontogenia após a eclosão. A coincidência do aumento em massa do ovo com o aumento da concentração de uréia evidencia possíveis relações entre a uréia e o potencial osmótico do ovo, e a possibilidade de promover absorção ou evitar a perda de água. 


\section{Discussão Geral}

Os ovos de iguana mostraram ser apropriados para utilização em experimentos fisiológicos e morfológicos pelo tamanho e ninhada numerosa, permitindo mais fácil manuseio e grande número de réplicas. Além disso, características como a casca pergaminácea ensejam uma série de questionamentos para um maior entendimento sobre as relações hídricas dos ovos e embriões, um tema que carece de mais investigações. É ainda interessante a possibilidade de comparação com representantes reptilianos de casca mais rígida.

O acúmulo de uréia, uma substância osmoticamente ativa, por um organismo, é uma estratégia para evitar a perda de água, através da criação de um potencial hídrico interno maior que o do meio externo. É um mecanismo energeticamente vantajoso por ser o produto final do catabolismo protéico (JORGENSEN, 1997). Este mecanismo é conhecido em anuros em período de estivação (WHITHERS e GUPPY, 1996) e elasmobrânquios durante a osmorregulação (FORSTER e GOLDSTEIN, 1976). Porém, um caso de acúmulo de osmólitos para propiciar a absorção de água é sugerido no caso da espécie de anfíbio anuro Eleutherodactylus coqui em que o balanço hídrico de sua desova é garantido através de transferência de água liquida do macho parental. Sugere-se que uma diferença no potencial hídrico entre o sangue do sapo e da camada gelatinosa de seus ovos é o que pode gerar o movimento de água do sapo parental para seus descendentes. Essa diferença de potencial hídrico seria causada pelo acúmulo de osmólitos, que poderia ser a uréia ou polissacarídeos, no espaço perivitelínico dos ovos (TAIGEN et al., 1984).

Assim como a pele dos anfíbios, no caso de ovos pergamináceos a absorção de água é facilitada, porém também é maior o risco de dessecação. Um mecanismo como o mencionado para os anfíbios poderia ser utilizado por ovos flexíveis quando incubados em situações de baixo potencial hídrico. O trabalho de Packard e Packard (1989) confirmou que existem inter-relações entre as trocas de águas pelos ovos e a concentração de uréia nos fluidos dentro dos ovos, porém, que também há influência sobre e o crescimento e utilização do vitelo dos embriões.

A média da massa dos filhotes de iguana é 30\% menor que a dos ovos próximos à eclosão e de $60 \%$ menor que nos ovos recém-desovados. Esses dados sugerem 
que, apesar do embrião apresentar um grande aumento em massa, a água absorvida é somente parcialmente incorporada aos seus tecidos. Apesar do mecanismo desconhecido, limitações hídricas interferem no crescimento embrionário e metabolismo, resultando em filhotes menores. Esses resultados foram reportados para répteis como tartarugas (TRACY et al., 1978, PACKARD et al., 1981) e lagartos (PACKARD et al., 1980), para aves, como a galinha doméstica (SIMKISS, 1980), anfíbios urodelos (HIGHTON e SAVAGE, 1961) e anuros (TAIGEN et al., 1984). Assim, a água absorvida, mesmo que não incorporada aos tecidos do embrião, influencia grandemente na aptidão do futuro filhote já que o tamanho dos animais pode influenciar na sobrevivência e em sua dispersão após a eclosão (JANZEN, 1993).

Uma outra hipótese para a absorção da água, é que ovos de cascas flexíveis possuem pouca albumina levando a vantagem de se poder produzir uma maior quantidade de ovos, mas ocupando menor espaço na cavidade corpórea e sendo mais leve para as fêmeas carregarem. Os ovos após a postura são capazes de absorver a água necessária ao metabolismo. Por sua vez, ovos de casca rígida necessitam de grande quantidade de albúmen durante sua formação no oviduto da fêmea, já que não possuem a capacidade de absorver grande quantidade de água do ambiente e subsistem ao longo do desenvolvimento a partir dessa reserva inicial e com uma pequena parcela de água formada metabolicamente (TRACY, 1980).

A partir da série de estágios embrionários elaborada para Iguana iguana será possível ampliar os estudos ecológicos, fisiológicos e evolutivos. A utilização de uma temperatura constante ao longo de todo o período embrionário favorece a elaboração de experimentos controlados e é importante porque durante as etapas de neurulação e organogênese são dependentes da temperatura assim como taxas de crescimento (ANDREWS, 2004).

É visível que enquanto o embrião está ainda em formação estrutural, que ocorre até os 45 dias, o aumento de uréia é progressivo e que em seguida quando o embrião passa a crescer, a concentração da uréia se torna significativamente maior e se mantêm até o final da eclosão. $\mathrm{O}$ crescimento mais pronunciado do embrião corresponde ao estágio 14, e é um período em que o embrião está totalmente formado e quando está ocorrendo crescimento das estruturas e maior consumo do vitelo remanescente. É interessante notar que o valor de concentração de uréia passa a ser 
significativo quando o embrião representa $10 \%$ da massa total do ovo, e quando já possui toda a fase de neurulação e organogênese completa.

O padrão de formação dos membros em tetrápodas pode ser utilizado como ferramenta para explicar um padrão filogenético. A heterocronia dos membros pode refletir uma funcionalidade, e assim uma vantagem evolutiva, como por exemplo, o que ocorre no gambá Didelphis virginiana, no qual os brotos dos membros anteriores se desenvolvem mais rapidamente do que em outras espécies de mamíferos (McCRADY, 1938). O desenvolvimento mais rápido dos membros anteriores ocorre devido a sua utilização pelos recém-nascidos para subir no marsúpio parental. Em anfíbios a ordem de aparecimento dos membros é bastante variável, mesmo se tratando de um único gênero (SHUMWAY, 1940; SCHRECKENBERG e JACOBSON, 1975; HARRISON, 1979), mas em répteis algum padrão filogenético parece existir. Em quelônios o desenvolvimento do membro anterior ocorre primeiro, à exceção das tartarugas marinhas, em que os membros anteriores e posteriores se desenvolvem sincronicamente (MILLER, 1985). Nos crocodilianos as espécies Caiman latirostris (IUNGMAN et al., 2008) e Caiman porosus (MAGNUSSON e TAYLOR, 1980) possuem o padrão reverso ao do crocodiliano pertencente a família Alligatoridae Alligator mississipiensis (FERGUSON, 1985). Em lagartos, foi encontrado que o desenvolvimento dos membros varia, porém ainda são necessários mais estudos para associá-los a padrões funcionais ou filogenéticos. Com as evidências destas heterocronias, é necessário identificar em futuros estudos, os mecanismos e elementos moleculares que são responsáveis pelas variações observadas no desenvolvimento de membros do grupo Squamata e demais répteis, e tentar posteriormente inferir as possíveis relações filogenéticas. 


\section{Conclusões}

- Foram identificados 18 estágios embrionários para Iguana iguana;

- Os estágios podem ser divididos mais genericamente em 3 fases de acordo com os critérios morfológicos mais significativos, os arcos branquiais, os membros e a pigmentação e escutelação;

- As características específicas da espécie são a prega gular, os escudos nucais, as cristas, e aparecem na fase final do desenvolvimento;

- Dentre as Tabelas embrionárias de lagartos é possível identificar heterocronia no desenvolvimento de membros, em que espécies da família Iguanidae pode ocorrer ora com desenvolvimento dos membros anteriores primeiro (Iguana iguana) ou com membros posteriores primeiro (Anolis sagrei);

- Diferenças estruturais e heterocrônicas da morfologia externa não possuem relação com a divisão de clados Iguania e Scleroglossa;

- A excreção de uréia foi predominante durante todo o desenvolvimento embrionário;

- O armazenamento de uréia se dá no alantóide enquanto os demais excretas distribuem-se proporcionalmente em todo o ovo;

- O ovos aumentam em duas vezes o valor de massa, e o momento do aumento significativo da massa corresponde ao período em que a uréia apresenta o maior valor de concentração e ao estágio em que o embrião está com organogêse completa e apenas aumenta em tamanho;

- Filhotes recém-eclodidos apresentaram maior proporção de produção de uréia, ao invés de excretar ácido úrico, típico dos adultos. 


\section{Resumo Geral}

Tabelas de estágio embrionário podem ser utilizadas para detectar semelhanças e diferenças de caracteres entre grupos e como ferramenta para estudos baseados na fase embrionária. Neste estudo, ovos do lagarto Iguana iguana foram utilizados para a elaboração de uma tabela de estágios e para determinar o padrão de excreção durante o desenvolvimento. Iguana é um modelo conveniente por produzir numerosas desovas de ovos de tamanho grandes, propiciando um fácil manuseio e um bom número de réplicas. Após a oviposição, 18 estágios embrionários foram determinados durante os quais uréia foi o resíduo nitrogenado principal. Apesar do iguana ser o primeiro lagarto estudado, o padrão ureotélico é comum entre a maioria das espécies reptilianas estudadas até o momento. A casca pergaminácea permite que os ovos dobrem em massa devido à absorção de água, e o mecanismo pelo qual os embriões lidam com a diluição e osmolaridade resultante é um tema interessante para futuros trabalhos e comparações com espécies de cascas rígidas. Há evidência de desenvolvimento heterocrônico dos membros e o desenvolvimento de iguana é similar ao do lagarto Anolis sagrei, também do clado Iguania. Mais estudos de desenvolvimento de lagartos são necessários e a utilização de critérios morfológicos similares para facilitar a comparação de eventos embrionários. 


\section{Abstract}

A Table of embryonic stages can be used to detect similarities and differences in developmental features between groups and as a tool for studies based on embryonic phase. In this study, eggs of the lizard Iguana iguana were used to elaborate a staging table and to determine the nitrogen excretion pattern during the development. Iguana is a convenient model for having a large clutch of large eggs, allowing an easy handling and a good number of replicates. After oviposition 18 embryonic stages were determined during which urea was the main nitrogen waste. Although iguana is the first lizard studied, the ureotelic pattern is common among the majority of reptilian species so far studied The pergaminaceous shell allows that the eggs double in mass due to water absorption, and the mechanism and how the egg deals with dilution and resultant osmolarity is an interesting issue for future works and comparisons with species of rigid eggshells. There is evidence of heterocronic development of the limbs and the development of iguana is similar to the lizard Anolis sagrei, also from the clade Iguania. Further studies on lizard development are required and the use of similar morphological approach to facilitate comparisons of embryonic events. 


\section{Referências Bibliográficas}

ACKERMAN, R. A. 1991. Physical factors affecting the water exchange of buried reptile eggs. In: Egg Incubation: Its Effects on Embryonic Development in Birds and Reptiles. Deeming, D. C e Ferguson, M. W. J. (eds), Cambridge University Press, Cambridge, pp. 193-211.

ANDREWS, R. M. 2004. Patterns of embryonic development, pp.75-102. In D. C. Deeming, Reptilian Incubation: Environment, Evolution and Behaviour, Nottingham: Nottingham University Press.

ANDREWS, R. M., MATHIES, T. 2000. Natural History of Reptilian Development: Constraints on the Evolution of Viviparity. BioScience, 50, 3, pp. 227-238.

BELLAIRS, R. 1991. Overview of early stages of avian and reptilian development, pp. 371-383. In D. C. Deeming \& M. W. J. Ferguson, Egg Incubation: Its Effects in Embryonic Development in Birds and Reptiles, Cambridge: Cambridge Univ. Press.

BILlET, F., GANS, C., MADERSON, P. F. A. 1985. Why study reptilian development? Pp. 1-32. In C. Gans, F. Billett and P. F. A. Maderson (eds), Biology of the Reptilia, Vol. 14-A. Wiley, New York.

BININDA-EMONDS, O. R. P.; JEFFERY, J. E.; SÁNCHEZ-VILLAGRA, M. R. et al. 2007. Forelimb-hindlimb developmental timing changes across tetrapod phylogeny. BMC Evolutionary Biology, Vol. 7, pp. 182.

BOUGHNER, J. C., BUCHTOVÁ, M., FU, K., DIEWERT, V., HALLGRÍMSSON, B., RICHMAN, J. M. 2007. Embryonic development of Python sebae - I: Staging criteria and macroscopic skeletal morphogenesis of the head and limbs. Zoology, 110, 212-230.

BRICKER, S. 2004. The Anaestesia Science. Greenwich Medical Media.

CARTledge V. A., Withers, P. C, McMAster, K. A., ThOMPSON, G. G., BRADSHAW, S. D. Water balance of field-excavated aestivating Australian desert frogs, the cocoonforming Neobatrachus aquilonius and the non-cocooning Notaden nichollsi (Amphibia: Myobatrachidae). Journal of Experimental Biology, 209, 3309-3332.

CHAN, A.O. K., DONG, M., WANG, L., CHAN, W. Y. 2005. Somite as a morphological reference for staging and axial levels of developing structures in mouse embryos. Neuroembryology and Aging, 3 (2):102-110.

CLARK, H. 1953. Metabolism of the black snake embryo. I. Nitrogen excretion. Journal of Experimental Biology, 30, pp. 492- 501. 
CLARK, H., SISKEN, B. F. 1956. Nitrogenous exretion by embryos of the viviparous snake Thamnophis s. sirtalis (L.). Journal of Experimental Biology, 33: 384-393.

CLARK, H., SISKEN, B., SHANNON, J. E. 1957. Excretion of nitrogen by the Alligator embryo. Journal of Cellular and Comparative Physiology, 50, 1, pp. 129-134.

CONRAD, J. L. 2008. Phylogeny And Systematics Of Squamata (Reptilia) Based On Morphology. Bulletin of the American Museum of Natural History, 310: 1-182.

CUNNINGHAM, B., HURWITZ A. P. 1936. Water Absorption by Reptile Eggs during Incubation. The American Naturalist, 70, 731, pp. 590-595.

DAVIS D. D., GORE, U.R. 1936. Clearing and staining skeleton of small vertebrates. Field Museum of Natural History, 4, pp. 3-15.

DEEMING, D. C., FERGUSON, M. W. 1991. Physiological effects of incubation temperature on embryonic development in birds and reptiles. In D. C. Deeming \& M. W. J. Ferguson, Egg Incubation: Its Effects in Embryonic Development in Birds and Reptiles, pp. 213-228, Cambridge: Cambridge University Press.

DINGERKUS, G., UHLER, L. 1977. Differential staining of bone and cartilage in cleared and stained fish using alcian blue to stain cartilage and enzymes for clearing fish. Stain Technology, 52, pp. 229-232.

DUFAURE J., HUBERT, J. P. 1961. Table de développement du lézard vivipare: Lacerta (Zootoca) vivipara Jacquin. Arch. Anat. Microscop. Morphol. Exp. 50, pp. 309-328. In PORTER, K. R. 1972. Herpetology. Philadelphia: WB Sounders, pp. 424-436.

ESTES, R., QUEIROZ, K., GAUTHIER, J. 1988. Phylogenetic Relationships within Squamata. Pp. 119-241. In: Estes, R., Pregill, G. (eds) Phylogenetic relationships of the lizard families. Stanford University Press, Stanford.

FISHER J. R., EAKIN R. E. 1957. Nitrogen Excretion in Developing Chick Embryos. Journal of Embryological and Experimental Morphology, 5, 3, pp. 215224.

FORSTER, R.P., GOLDSTEIN, L. 1976. Intracellular osmoregulatory role of amino acids and urea in marine elasmobranchs. American Journal of Physiology, 230, 4, pp. 925-931.

HAGGAG, G. 1964. Nitrogenous excretion in snakes embryo. Zeitschrift für vergleichende Physiologie, 48, 462-466.

HAND, S. C., SOMERO, G. N. 1982. Urea and methylamine effects on rabbit muscle phosphofructokinase. Catalytic stability and aggregation state as a function of $\mathrm{pH}$ and temperature. The Journal of Biological Chemistry, 257: 734-741. 
GIRONS, H. S. 1985. Comparative data on lepidosaurian reproduction and some time tables. Pp. 35-58. In C. Gans, F. Billett and P. F. A. Maderson (eds), Biology of the Reptilia, 15. Wiley, New York.

HAMBURGER, V.; HAMILTON, H. L. 1951. A series of normal stages in the development of the chick embryo. Journal of Morphology, 88, 1.

HARRISON, R. G. 1969. Harrison stages and description of the normal development of the spotted salamander, Amblystoma punctatum (Linn). In: Wilens, S. Organization and development of the embryo. New Haven: Yale University Press, pp. 44-66.

HENDERSON, R. W. 1974. Aspects of the Ecology of the Juvenile Common Iguana (Iguana iguana). Herpetologica, 30 (4), pp. 327-332.

HIGHTON R., SAVAGE, T. 1961. Functions of the brooding behavior in the female red-backed salamander, Plethodon cinereus. Copeia, 1961 (1), 95-98.

HIRTH, H. F. 1963. The ecology of two lizards on a tropical beach. Ecological Monographs, 33 (2): 83-112.

HOPWOOD, N. 2007. A history of normal plates, tables and stages in vertebrate embryology. International Journal of Developmental Biology, 51 (1): 1-26.

HUBERT, J. 1985. Embryology of the Squamata. Pp. 1-34. In C. Gans, F. Billett and P. F. A. Maderson (eds), Biology of the Reptilia, 15. Wiley, New York.

IUNGMAN J.; PIÑA C. L.; SIROSKI P. 2008. Embryological Development of Caiman latirostris (Crocodylia: Alligatoridae). Genesis, 46, pp. 401-417.

JACKSON, K. 2002. Post-ovipositional development of the monocled cobra, Naja kaouthia (Serpentes: Elapidae). Zoology, 105: 203-214.

JANZEN, F. J. 1993. An experimental analysis of natural selection on body size of hatchling turtles. Ecology, 74 (2): 332-341.

JORGENSEN, C. B. 1997. Urea and Amphibian Water Economy. Comparative. Biochemical Physiology, 117 A, 2, pp. 161-170.

LEMUS, D., ILlANES, J., FUENZALIDA, M., VEGA, Y. P., GARCIA, M. 1981. Comparative analysis of the development of the lizard Liolaemus tenuis tenuis. II. A series of normal postlaying stages in embryonic development. Journal of Morphology, 169, pp. 337-349.

LICHT, P.; MOBERLY, W. R. Thermal Requirements for Embryonic Development in the Tropical Lizard Iguana iguana. Copeia, 1965, 4, pp. 515-517, 1965. 
McCRADY, E. 1938. The embryology of the opossum. American Anatomical Memoirs 16, 1-226.

McKHANN, G. M., TOWER, D. B. 1961. Ammonia toxicity and cerebral oxidative metabolism. American Journal of Physiology, 200 (3): 420-424.

McNABB, R. A., McNABB, F. M. A. 1980. Physiological chemistry of uric acid: solubility, colloid and ion-binding properties. Comparative Biochemical Physiology A, 67 (1): 27-34.

MAGNUSSON, W. E., TAYLOR, J. A. 1980. A Description of Developmental Stages in Crocodylus porosus, for Use in Aging Eggs in the Field. Australian Wildlife Research, 7 (3): 479 - 485.

MILLER, J. D. Embryology of marine turtles. . In C. Gans, F. Billett and P. F. A. Maderson (eds), Biology of the Reptilia, 14-A. Wiley, New York.

MOUDEN, E. EL., BONS, J. PIEAU C., RENOUS, S., ZNARI, M., BOUMEZZOUGH, A. 2000. Table de développement embryonnaire d'un lézard agamidé, Agama impalearis Boettger, 1874. Annales des Sciences Naturelles 21, 3, pp. 93-115.

MOYLE, V. 1949. Nitrogenous Excretion in Chelonian Reptiles. Biochemical Journal, 44 (5): 581-584.

MÜLLER, G. B. 1991. Evolutionary transformation of limb pattern: heterocrony and secondary fusion. In: J. R. Hinchliffe et al. Developmental Patterning of the Vertebrate Limb. New York: Plenum Press, pp.395-405.

MUTHUKKARUPPAN, V., KANAKAMBIKA, P., MANICKAVEL, V., VEERARAGHAVAN. 1970. Analysis of the development of the lizard, Calotes versicolor, I. a series of normal stages in the embryonic development. Journal of Morphology, 130, pp. 479-490.

NEEDHAM, J. 1931. Chemical embryology. Cambridge University Press, London, United Kingdom, 105p.

NORO, M.; UEJIMA A.; ABE, G.; MANABE, M.; TAMURA, K. 2009. Normal developmental stages of the Madagascar ground gecko Paroedura pictus with special reference to limb morphogenesis. Developmental Dynamics 238, 100-109.

OPIE, E. L., 1956. Changes in the osmotic activity of liver and of kidney tissue caused by passage of sodium chloride, urea, and some other substances into cells. Journal of Experimental Medicine, 103 (3): 351-362.

PACKARD, G. C. 1966. The Influence of Ambient Temperature and Aridity on Modes of Reproduction and Excretion of Amniote Vertebrates. The American Naturalist, 100, 916, pp. 667-682. 
PACKARD, G. C. 1991. Physiological and ecological importance of water to embryos of oviparous reptiles. In: Egg incubation: Its Effects on Embryonic Development in Birds and Reptiles. Deeming, D. C e Ferguson, M. W. J. (eds), Cambridge University Press, Cambridge, pp. 213-228.

PACKARD, G. C., PACKARD, M. J., BOARDMAN, T. J., ASHEN, M. D. 1981. Possible Adaptive Value of Water Exchanges in Flexible-Shelled Eggs of Turtles. Science, New Series, 213, 4506, pp. 471-473.

PACKARD, M. J.; PACKARD, G. C.; BOARDMAN T.J. 1982. Structure of eggshells and water relations of reptilian eggs. Herpetologica, 38, pp.136-155.

PACKARD G. C; PACKARD M. J. 1983. Patterns of Nitrogen Excretion by Embryonic Softshell Turtles (Trionyx spiniferus) Developing in Cleidoic Eggs. Science, v. 221, 4615, pp. 1049-1050.

PACKARD, G. C., PACKARD, M. J., BOARDMAN, T. J., MORRIS, K. A., SHUMAN, R. D. 1983. Influence of Water Exchanges by Flexible-Shelled Eggs of Painted Turtles Chrysemys picta on Metabolism and Growth of Embryos. Physiological Zoology, 56, 2, pp. 217-230.

PACKARD, G. C.; PACKARD, M. J.; BOARDMAN, T. J. 1984. Influence of hydration of the Environment on the pattern of nitrogen excretion by embryonic snapping turtles (Chelydra serpentina). Journal of Experimental Biology, 108, pp. 195-204.

PACKARD, G. C.; PACKARD, M. J.; GUTZKE, W. H. N. 1985. Influence of Hydration of the Environment on Eggs and Embryos of the Terrestrial Turtle Terrapene ornata. Physiological Zoology, 58, 5, p. 564-575.

PACKARD, G. C.; PACKARD, M. J. 1987. Water Relations and Nitrogen Excretion in Embryos of the Oviparous Snake Coluber constrictor. Copeia, 1987, 2, pp. 395406.

PACKARD G. C, PACKARD, M. J. 1989. Control of metabolism and growth in embryonic turtles: a test of the urea hypothesis. Journal of Experimental Biology 147, pp. 203-216.

PORTER, K. R. 1972. Herpetology. Philadelphia: WB Sounders, pp. 168-432.

RAHN H., AR A.; PAGANELli C. V. 1979. How bird eggs breathe. Scientific American, 240, 2, pp. 46-55.

RAND, A. S, DUGAN B. 1983. Structure of Complex Iguana Nests Copeia, 1983 (3): pp. 705-711.

RANDALL, D. J., WRIGHT, P. A. 1987. Ammonia distribution and excretion in fish. Fish Physiology and Biochemistry, 3 (3): 107-120. 
RICHARDSON, M. K. 1999. Vertebrate evolution: the developmental origins of adult variation. Bio Essays, 21: 604-613.

ROMER, A. S. 1957. Origin of the Amniotic Egg, The Scientific Monthly, 85, 2, pp. 57-63.

SANGER, T. J.; LOSOS J. B.; GIBSON-BROWN, J. J. 2008. A developmental staging series for the lizard genus Anolis: a new system for the integration of evolution, development, and ecology. Journal of Morphology, 269, 129-137.

SCHRECKENBERG, G. M. AND JACOBSON, A. G. 1975. Normal Stages of development of the axolotl. Developmental Biology, 42, 391-400.

SHINE, R. 1983. Reptilian Reproductive Modes: The oviparity-viviparity continuum. Herpetologica. 39, 1, 1-8.

SHUMWAY, W. 1940. Stages in the normal development of Rana pipiens I. External form. The Anatomical Record, 78 (2): 139-147.

SIMKISS, K. 1980. Water and Ionic Fluxes Inside the Egg. American Zoologist, 20 (2): 385-393.

SLACK, J. M. W., HOLLAND, P. W. H., GRAHAM, C. F. 1993. The zootype and phylotypic stage. Nature, 361, 490-492.

SMITH, K. K. 2003,Time's arrow: heterochrony and the evolution of development. International Journal of Developmental Biology, 47, pp. 613-621.

TAIGEN, T. L., POUGH, F. H., STEWART, M. M. 1984. Water balance of terrestrial anuran (Eleutherodactylus coqui) eggs: importance of parental care. Ecology 65, 248-255.

THOMPSON, M. B. 1987. Water Exchange in Reptilian Eggs. Physiological Zoology, 60, 1, pp. 1-8.

TOWNSEND, T. M., LARSON, A., LOUIS, E., MACEY. J. R. 2004. Molecular phylogenetics of squamata: the position of snakes, amphisbaenians, and dibamids, and the root of the squamate tree. Systematic Biology, 53 (5): 735-757.

TRACY, C. R. 1980. Water relations of parchment-shelled lizard (Sceloporus undulatus) eggs. Copeia, 1980, 3, pp. 478-482.

TRACY, C. R., PACKARD, G. C., PACKARD, M. J. 1978. Water Relations of Chelonian Eggs. Physiological Zoology, 51 (4): 378-387.

TRACY, C. R.; SNELL, H. L. 1985. Interrelations among water and energy relations of reptilian eggs, embryos and hatchlings, American Zoologist, 25, pp. 999-1008. 
TROYER, K. 1982. Transfer of fermentative microbes between generations in a herbivorous lizard. Science, 216, pp. 540-542.

TROYER, K. 1984a. Structure and function of the digestive tract of a herbivorous lizard Iguana iguana. Physiological Zoology, 57 (1) pp. 1-8.

TROYER, K. 1984b. Diet selection and digestion in Iguana iguana: the importance of age and nutrient requirements. Oecologia, 61 (2): 201-207.

VERDOUW, H., Van Echteld, C. J. A., Dekkers, E. M. J. 1978. Ammonia determination based on indophenol formation with sodium salicylate. Water Research, 12, pp. 399-402.

VIDAL, N., HEDGES, S. B. 2005. The phylogeny of squamate reptiles (lizards, snakes and amphisbaenians) inferred from nine nuclear protein-coding genes. C. $R$. Biologies, 328, pp. 1000-1008.

VITT, L. J., PIANKA, E. R., COOPER, W. E., SCHWENK, K. 2003. History and the global ecology of squamate reptiles. American Naturalist, 162 (1), pp. 44-60.

VLECK, D. 1991. Water economy and solute regulation of reptilian and avian embryos. In: Egg Incubation: Its Effects on Embryonic Development in Birds and Reptiles. Deeming, D. C e Ferguson, M. W. J. (eds), Cambridge University Press, Cambridge, pp.245-260.

VLECK, C. M.; HOYT, D. F. 1991. Metabolism and energetics of reptilian and avian embryos, p. 285-306. In D. C. Deeming \& M. W. J. Ferguson, Egg Incubation: Its Effects in Embryonic Development in Birds and Reptiles, Cambridge: Cambridge Univ. Press.

WARREN, F. W.; LIEM, K. F. 1994. Functional Anatomy of the Vertebrates: An Evolutionary Perspective. Florida: Sounders College, 2a edição, pp. 711-734.

WISE, P. A. D., VICKARYOUS M. K., RUSSELL A. P. 2009. An embryonic staging table for in ovo development of Eublepharis macularius, the leopard gecko. The Anatomical Record, 292, 1198-1212.

WITHERS, P. C., GUPPY, M. 1996. Do Australian desert frogs co-accumulate counteracting solutes with urea during aestivation? Journal of Experimental Biology, 199: 1809-1816.

WRIGHT, P. A. 1995. Nitrogen Excretion: three end products, many physiological roles. Journal of Experimental Biology, pp. 273-281.

ZEHR, D. R. 1962. Stages in the normal development of the common garter snake, Thamnophis sirtalis sirtalis. Copeia, 1962 (2): 322-329. 


\section{Anexos e Apêndices}

Apêndice 1: Comparação dos eventos de desenvolvimento de iguana, separados por estágios, correlacionados com os respectivos estágios onde são descritos para as demais espécies de lagartos. Para facilitar comparações, os estágios de iguana possuem entre parênteses a sequência de estágios a partir do estágio 28, que é o estágio equivalente ao de L. vivípara no momento da oviposição. No caso de Paroedura pictus a denominação dpo significa "dias pós-oviposição". Asteriscos (*) denotam características espécie-específicas de iguana. Legenda: 1. Anolis sagrei (SANGER et al., 2008); 2. Agama impalearis (MOUDEN et al., 2000); 3. Liolaemus tenuis tenuis (LEMUS et al., 1981); 4. Calotes versicolor (MUTHUKKARRUPPAN et al., 1970); 5. Eublepharis macularius (WISE et al., 2009); 6. Paroedura pictus (NORO et al., 2009); 7. Lacerta vivipara (DUFAURE e HUBERT, 1961). 


\begin{tabular}{|c|c|c|c|c|c|c|c|}
\hline I. iguana & A. sagrei $^{1}$ & A. impalearis ${ }^{2}$ & L. tenuis ${ }^{3}$ & C. versicolor ${ }^{4}$ & E. macularius ${ }^{5}$ & $P \cdot$ pictus $^{6}$ & L.vivipara \\
\hline $\begin{array}{l}\text { Estágio } 1 \text { (28) } \\
\text { brotos dos membros ant. e post. presentes } \\
\text { broto da cauda com } 1 \text { pequena volta } \\
3 \text { ou } 4 \text { arcos branquiais visíveis } \\
\text { olhos sem pigmentação } \\
3 \text { vesículas cerebrais visíveis } \\
\text { vesícula ótica evidente } \\
\text { placódio nasal notório }\end{array}$ & $\begin{array}{l}\text { est } 3 \\
\text { est } 3 \\
\text { est } 1 \\
\text { est } 1 \\
\text { est } 1\end{array}$ & est 28 & $\begin{array}{l}\text { est } 30 \\
\text { est } 30 \\
\text { est } 30 \\
\text { est } 30 \\
\text { est } 30\end{array}$ & $\begin{array}{l}\text { est } 29 \\
\text { est } 29\end{array}$ & $\begin{array}{l}\text { est } 29 \\
\text { est } 28\end{array}$ & $\begin{array}{l}3 \text { dpo } \\
2 \text { dpo }\end{array}$ & $\begin{array}{l}\text { est } 28 \\
\text { est } 28\end{array}$ \\
\hline $\begin{array}{l}\text { Estágio } 2 \text { (29) } \\
5 \text { arcos branquiais } \\
\text { membros maiores; membro anterior maior } \\
\text { fissura coróide aparente; } \\
\text { pigmentação retina } \\
\text { mesencéfalo mais evidente } \\
\text { metencéfalo e diencéfalo evidentes }\end{array}$ & $\begin{array}{l}\text { est } 4 \\
\text { est } 1 \\
\text { est } 2\end{array}$ & $\begin{array}{l}\text { est } 28 \\
\text { est } 32 \\
\text { est } 29\end{array}$ & $\begin{array}{l}\text { est } 31 \\
\text { est } 31\end{array}$ & est 30 & est 29 & $\begin{array}{l}3 \text { dpo } \\
4 \text { dpo }\end{array}$ & est 30 \\
\hline $\begin{array}{l}\text { Estágio } 3 \text { (30) } \\
\text { torção cervical } \\
2^{\circ} \text { arco branquial cobre o } 3^{\circ} \\
\text { contorno da lente nos olhos } \\
\text { placódio nasal menos evidente } \\
\text { maior pigmentação olhos } \\
\text { divergência direção cresci/o membros } \\
\text { vesículas cerebrais maiores }\end{array}$ & $\begin{array}{l}\text { est } 5 \\
\text { est } 3\end{array}$ & est 31 & $\begin{array}{l}\text { est } 34 \\
\text { est } 35 \\
\text { est } 36\end{array}$ & 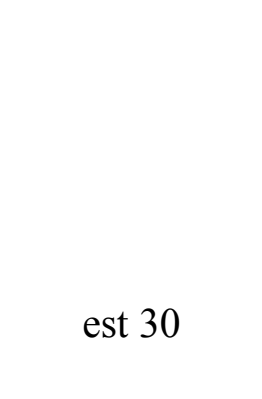 & $\begin{array}{l}\text { est } 31 \\
\text { est } 30\end{array}$ & & \\
\hline
\end{tabular}


Tabela 1: Comparação de eventos com os estágios equivalentes de desenvolvimento em espécies dos clados Iguania e Scleroglossa (continuação)

\begin{tabular}{|c|c|c|c|c|c|c|c|}
\hline I. iguana & A. sagrei ${ }^{l}$ & A. impalearis $^{2}$ & L. tenuis ${ }^{3}$ & C. versicolor ${ }^{4}$ & E. macularius ${ }^{5}$ & $P \cdot$ pictus $^{6}$ & L.vivipara $^{7}$ \\
\hline $\begin{array}{l}\text { Estágio } 4 \text { (31) } \\
\text { projeção dos processos maxil. e mandib. } \\
\text { divisão lobos telencefálicos } \\
\text { fusão arcos branquiais } 1 \text { e } 2 \\
3 \text { projeta-se sobre } 4 \text { e } 5 \\
\text { olhos em elipse e maiores } \\
\text { extremidade dos membros achata levemente }\end{array}$ & $\begin{array}{l}\text { est } 5 \\
\text { est } 6 \\
\text { est } 3 \\
\text { est } 4 \\
\text { est } 4\end{array}$ & est 31 & $\begin{array}{l}\text { est } 38 \\
\text { est } 35\end{array}$ & est 31 & & $12 \mathrm{dpo}$ & \\
\hline $\begin{array}{l}\text { Estágio } 5 \text { (32) } \\
\text { formação do autopódio, forma de raquete } \\
\text { proc.mandib. em direção posterior aos olhos } \\
\text { maxilares estendidos até proximal dos olhos } \\
\text { pigmentação uniforme da retina } \\
\text { fissura coróide fechada } \\
\text { lobos diencefálicos expandidos }\end{array}$ & $\begin{array}{l}\text { est } 6 \\
\text { est } 5\end{array}$ & $\begin{array}{l}\text { est } 31 \\
\text { est } 29\end{array}$ & est 36 & $\begin{array}{l}\text { est } 32 \\
\text { est } 33 \\
\text { est } 30\end{array}$ & $\begin{array}{l}\text { est } 31 \\
\text { est } 30 \\
\text { est } 29\end{array}$ & $6 \mathrm{dpo}$ & $\begin{array}{l}\text { est } 31 \\
\text { est } 33 \\
\text { est } 31\end{array}$ \\
\hline $\begin{array}{l}\text { Estágio } 6 \text { (33) } \\
\text { condensação dos dígitos } \\
\text { delinea/o estilopódio e zeugopódio } \\
\text { proc. maxilar une-se ao proc. nasal lateral } \\
\text { proc. mand. estendido até margem medial dos } \\
\text { olhos } \\
\text { diferenciação da íris } \\
\text { divisão mesencéfalo em } 2 \text { lobos }\end{array}$ & $\begin{array}{l}\text { est } 8 \\
\text { est } 8 \\
\text { est } 8 \\
\text { est } 6 \\
\text { est } 8\end{array}$ & $\begin{array}{l}\text { est } 33 \\
\text { est } 33 \\
\text { est } 31\end{array}$ & est 37 & est 33 & $\begin{array}{l}\text { est } 32 \\
\text { est } 31 \\
\text { est } 32 \\
\text { est } 30\end{array}$ & 8 dpo & $\begin{array}{l}\text { est } 34 \\
\text { est } 32\end{array}$ \\
\hline
\end{tabular}


Tabela 1: Comparação de eventos com os estágios equivalentes de desenvolvimento em espécies dos clados Iguania e Scleroglossa (continuação)

\begin{tabular}{|c|c|c|c|c|c|c|c|}
\hline I. iguana & A. sagrei & A. impalearis & L. tenuis & C. versicolor & E. macularius & $P . \underset{6}{P}$ pictus & L.vivipara \\
\hline $\begin{array}{l}\text { Estágio } 7 \text { (34) } \\
\text { membrana interdigital e condensação dígitos completa } \\
\text { primórdio do hemipênis } \\
\text { ductos endolinfáticos } \\
\text { processo maxilar une-se ao processo nasal medial } \\
\text { processos mand. estendidos até porção distal olhos } \\
\text { lobos telenc. e mesenc. menores e mais próximos }\end{array}$ & $\begin{array}{l}\text { est } 8 \\
\text { est } 10 \\
\text { est } 9 \\
\text { est } 10\end{array}$ & est 32 & est 34 & est 34 & est 34 & $\begin{array}{l}22 \mathrm{dpo} \\
16 \mathrm{dpo}\end{array}$ & $\begin{array}{l}\text { est } 35 \\
\text { est } 31 \\
\text { est } 30\end{array}$ \\
\hline $\begin{array}{l}\text { Estágio } 8 \text { (35) } \\
\text { membr. interdigital pacial/e reduzida } \\
\text { maxila superior total/e formada } \\
\text { proc. mandibular alcança direção do maxilar } \\
\text { pineal evidente } \\
\text { hemipênis mais desenvolvido } \\
\text { mesencéfalo menor e mais próximo do diencéfalo }\end{array}$ & $\begin{array}{l}\text { est } 9 \\
\text { est } 10 \\
\text { est } 12\end{array}$ & $\begin{array}{l}\text { est } 35 \\
\text { est } 34 \\
\text { est } 40\end{array}$ & est 38 & $\begin{array}{l}\text { est } 35 \\
\text { est } 35 \\
\text { est } 33\end{array}$ & $\begin{array}{l}\text { est } 35 \\
\text { est } 34 \\
\text { est } 35\end{array}$ & & $\begin{array}{l}\text { est } 34 \\
\text { est } 35 \\
\text { est } 35\end{array}$ \\
\hline $\begin{array}{l}\text { Estágio } 9 \text { (36) } \\
\text { membrana interdigital ausente } \\
\text { parede do corpo fechada } \\
\text { início formação pálpebras }\end{array}$ & $\begin{array}{l}\text { est } 11 \\
\text { est } 10\end{array}$ & $\begin{array}{l}\text { est } 36 \\
\text { est } 34 \\
\text { est } 33\end{array}$ & $\begin{array}{l}\text { est } 40 \\
\text { est } 39\end{array}$ & $\begin{array}{l}\text { est } 36 \\
\text { est } 34\end{array}$ & $\begin{array}{l}\text { est } 36 \\
\text { est } 34\end{array}$ & & est 33 \\
\hline $\begin{array}{l}\text { Estágio } 10 \text { (37) } \\
\text { escleras ópticas } \\
\text { hemipenis maior } \\
\text { início formação garras } \\
\text { primórdio de escamas (maior magnificação) }\end{array}$ & $\begin{array}{l}\text { est } 11 \\
\text { est } 13\end{array}$ & $\begin{array}{l}\text { est } 34 \\
\text { est } 36\end{array}$ & & est 37 & $\begin{array}{l}\text { est } 37 \\
\text { est } 35\end{array}$ & $\begin{array}{l}28 \mathrm{dpo} \\
18 \mathrm{dpo}\end{array}$ & $\begin{array}{l}\text { est } 34 \\
\text { est } 35 \\
\text { est } 36\end{array}$ \\
\hline $\begin{array}{l}\text { Estágio } 11 \text { (38) } \\
\text { escudos nucais * } \\
\text { crista occpital e dorsal * }\end{array}$ & & & & & & & \\
\hline
\end{tabular}


Tabela 1: Comparação de eventos com os estágios equivalentes de desenvolvimento em espécies dos clados Iguania e Scleroglossa (continuação)

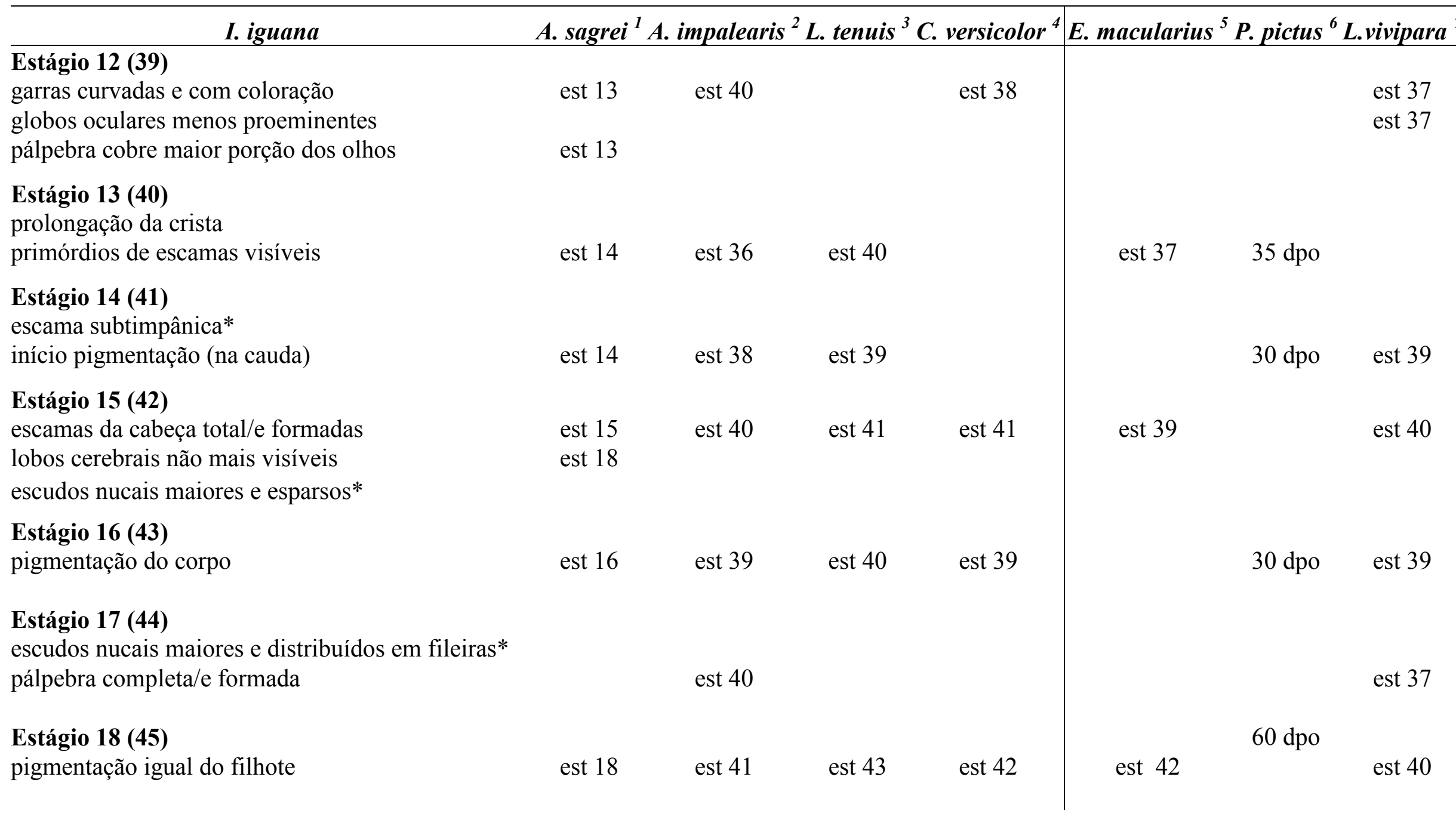

